\title{
DEVELOPMENT OF A DIGITAL MODEL OF GROUND-WATER FLOW IN DEEPLY WEATHERED CRYSTALLINE ROCK, CHESTER COUNTY, PENNSYLVANIA
}

\section{U.S. GEOLOGICAL SURVEY}

WATER RESOURCES INVESTIGATIONS $\mathbf{8 0 - 2}$

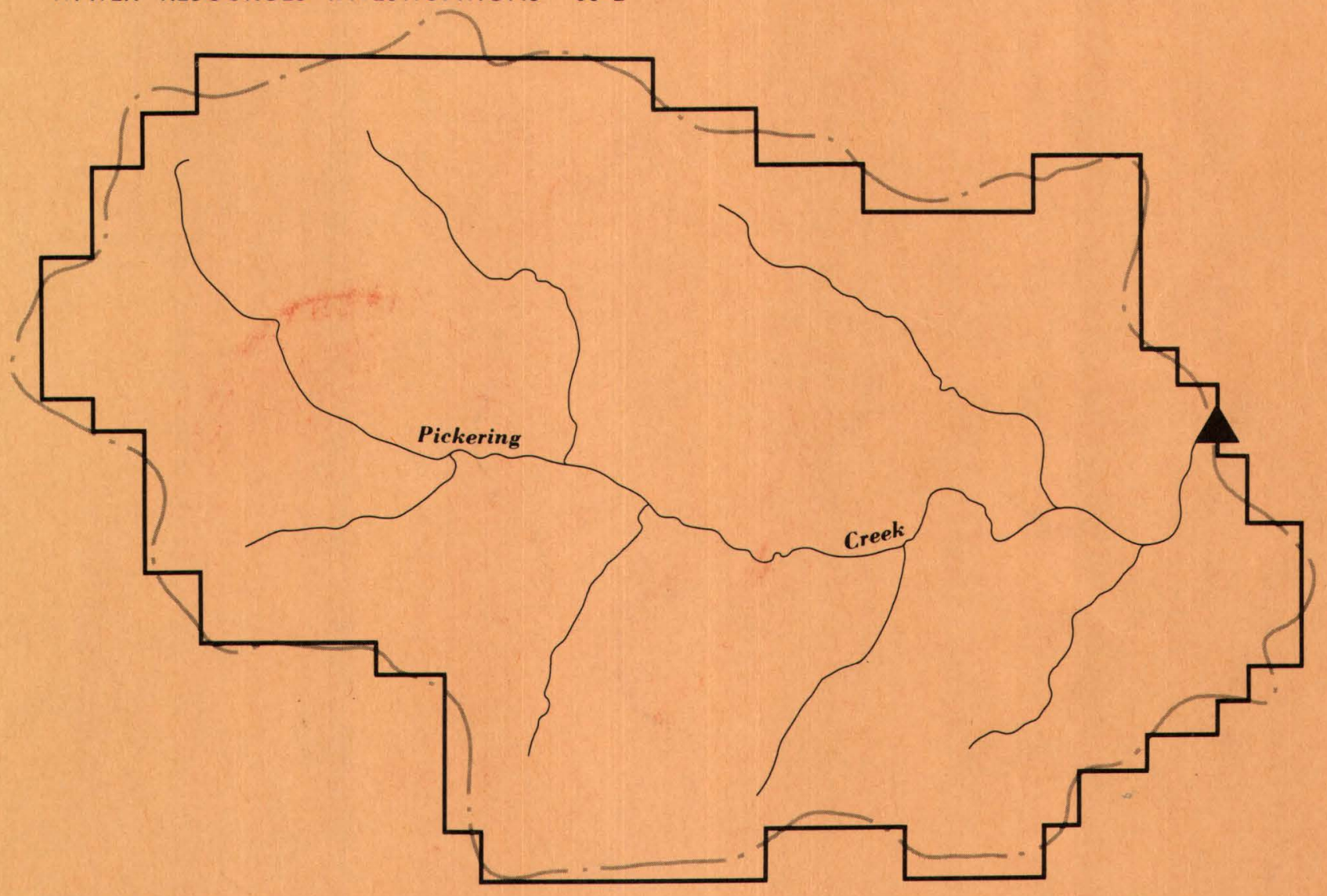

Prepared in Cooperation with the

CHESTER COUNTY WATER RESOURCES AUTHORITY 


\begin{tabular}{|l|l|}
\hline REPORT DOCUMENTATION & 1. REPORT NO. \\
PAGE
\end{tabular}

4. Title and Subtitle

Development of a digital model of ground-water flow in deeply weathered crystalline rock, Chester County, Pennsylvania

\section{Author(s)}

Laurence J. McGreevy, and Ronald A. Sloto

9. Performing Organization Name and Address

U.S. Geological Survey, Water Resources Division

P.0. Box 1107,228 Walnut Street

Harrisburg, Pennsylvania 17108

12. Sponsoring Organization Name and Address

U.S. Geological Survey, Water Rescurces Division

P.0. Box 1107, 228 Walnut Street

Harrisburg, Pennsylvania 17108
3. Recipient's Accession No.

5. Report Date

March, 1980

6.

8. Performing Organization Rept. No. USGS/WRI-80-2

10. Project/Task/Work Unit No.

11. Contract(C) or Grant(G) No.

(C)

(G)

13. Type of Report \& Period Covered

Final

14.

15. Supplementary Notes

Prepared in cooperation with the Chester County Water Resources Authority

16. Abstract (Limit: 200 words) The model simulates recharge to, flow through, and discharge from the water-table aquifer in a 5.98 square mile basin representative of most of Chester County, Pennsylvania. The two-dimensional finite-difference model of Trescott, Pinder, and Larson was used. The way ground-water evapotranspiration varies with depth was modified, and a minimum transmissivity was added to prevent the model from "going dry".

Tests of the model showed good correlation with field data, but also showed that additional information would make the model more reliable. Particularly helpful would be more water-level and evapotranspiration data, synoptic base-flow measurements, and information on the variation of permeability and specific yield with depth.

Residential development was simulated in 1 square mile of the basin using combinations of the following conditions: 1 acre, 1/2-acre, and 1/4-acre. lot size; wastewater disposal by septic systems or by public sewering; domestic wells or public-supply wells for water supply; and 0,1 , and 5 percent reduction in recharge in the developed area. Where domestic water is supplied by local ground water, decreased lot size and reduced recharge cause increased drawdowns and reduced base flow. When wastewater is exported by sewers, these effects are magnified.

17. Document Analysis a. Descriptors

*Model, *water-table, *weathered rock, *surface- ground-water relationships, *base flow, crystalline rocks, land development Pennsylvania, Piedmont

b. Identifiers/Open-Ended Terms

Chester County, Pickering Creek

c. COSATI Field/Group

18. Availability Statement

No restriction on distribution

\begin{tabular}{|l} 
19. Security Class (This Report) \\
UNCLASSIFIED \\
\hline 20. Security Class (This Page) \\
UNCLASS IFIED
\end{tabular}

See Instructions on Reverse
21. No. of Pages 42

22. Price

OPTIONAL FORM $272(4-77)$

(Formerly NTIS-35)

Department of Commerce 
DEVELOPMENT OF A DIGITAL MODEL OF GROUND-WATER FLOW IN

DEEPLY WEATHERED CRYSTALLINE ROCK, CHESTER COUNTY, PENNSYLVANIA

By Laurence J. McGreevy and Ronald A. Sloto

U.S. GEOLOGICAL SURVEY

Water-Resources Investigations 80-2

Prepared in cooperation with the

Chester County Water Resources Authority

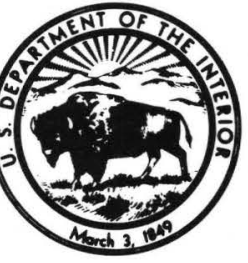

August 1980 


\title{
UNITED STATES DEPARTMENT OF THE INTERIOR
}

CECIL D. ANDRUS, Secretary

\author{
GEOLOGICAL SURVEY
}

H. William Menard, Director

For additional information write to:

U.S. Geological Survey

4th Floor, Federal Building

P.0. Box 1107

Harrisburg, Pennsylvania 17108 
Conversion of units of measurement

Abstract --_-_-

Introduction -

Purpose and scope --_-_-_-_- 3

Selection of model area --

Local hydrology -

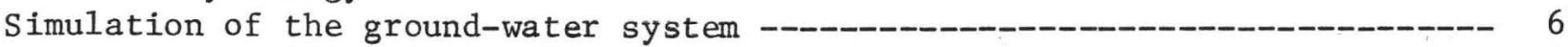

Model selection --_-_- 6

General model-development procedures --_- - - - -

Boundary conditions - - - - -

Hydrologic parameters --_-_-_-

Transmissivity -

Hydraulic conductivity and BOTTOM -

Minimum transmissivity --__- 17

Specific yield and storage coefficient -

Leakage to and from streams --_-_-_-_-_-_-_-_-_-_-_-_-_--_-_--- 18

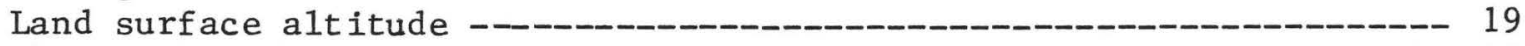

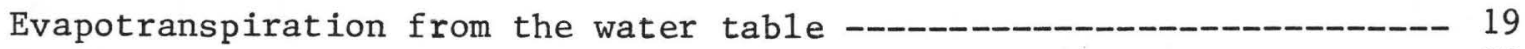

Recharge --_-_-_-_- 22

Ground-water pumpage --_-_-_-_-_- 22

Testing the mode1 -

Utilization of the model

Initial conditions -

Prediction simulations -

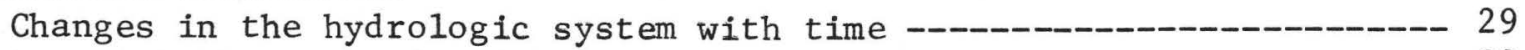

Sewering the undeveloped basin - 32

Sewering the area of development -

Comparison of domestic and public-supply wells ---_----------------- 35

Lot size - -

Reduction in recharge -- 38

Conclusions -- - - - - - - - -

Selected References --_-_- 
Figure 1.--Map showing location of modeled area ---

2.--Geologic map of modeled area -

3.--Map showing approximate water-level contours in modeled area -- - 7

4.--Finite-difference grid --_- 8

5.--Method of estimating initial transmissivity values --------- 13

6.--Transmissivity values used in the final steady-state calibration run --_-- 15

7.--Assumed relation between hydraulic conductivity and transmissivity --_- 17

8.--Relation of ground-water evapotranspiration rate to depth of the water table used in the model

9.--Hydrograph of Pickering Creek near Chester Springs and simulated hydrograph of base flow, August 1975 to December 1976

10.--Simulated base flow for August 20, 1975

11.--Graph showing relation of low-flow measurements to simulated base flow --_-

12.--Simulated water-level hydrograph compared to observed hydrograph of we11 $\mathrm{CH}-2328$

13.--Simulated water level at node 16,6 compared to observed water leve1 in we11 CH-1229

14.--Map showing simulated area of development -

15.--Maps showing simulated decline in water level, and graph of reduction in average base flow with time. Area of development is divided into $\frac{1}{2}$-acre lots with domestic wells and public sewers

16.--Map showing simulated decline in water level 20 years after sewering the undeveloped basin -

17.--Map showing simulated decline in water level after 20 years of pumping. Area of development is divided into $I_{2}$-acre lots with domestic wells and septic systems -...-. $30-32$

18-22.--Maps showing simulated decline in water level and graphs showing reduction in average base flow after 20 years of pumping. Area of development is divided into lots with public water and sewers:

18. - $\frac{1}{2}$-acre lots --

19.--1-acre lots -- --

20.-- $\frac{1}{4}-$ acre lots --

21. $-\frac{1}{2}-$ acre lots. Recharge is reduced 1 percent over the area of development -

22. $--\frac{1}{2}-$ acre lots. Recharge is reduced 5 percent over the area of development 
Table 1.--Hydrologic parameters used in the model

FACTORS FOR CONVERTING INCH-POUND UNITS TO INTERNATIONAL

SYSTEM UNITS (SI)

Mu1tiply inch-pound unit

inch (in.)

foot ( $f t$ )

mile (mi)

square mile $\left(\mathrm{mi}^{2}\right)$

acre

cubic foot per second $\left(\mathrm{ft}^{3} / \mathrm{s}\right)$

gallon per minute (gal/min)

million gallons per day

( $\mathrm{Mga1} / \mathrm{d})$

million gallons per year

(Mga1/yr)
$\underline{B y}$

25.4

0.3048

1.6093

2.59

4047

0.4047

0.004047

28.32

0.02832

0.06309

0.04381

0.00012
To obtain SI units

millimeter (mm)

meter (m)

kilometer $(\mathrm{km})$

square kilometer $\left(\mathrm{km}^{2}\right)$

square meter $\left(\mathrm{m}^{2}\right)$

hectare (ha)

square kilometer $\left(\mathrm{km}^{2}\right)$

liter per second (L/s)

cubic meter per second $\left(\mathrm{m}^{3} / \mathrm{s}\right)$

liter per second (L/s) cubic meters per second $\left(\mathrm{m}^{3} / \mathrm{s}\right)$

cubic meters per second $\left(\mathrm{m}^{3} / \mathrm{s}\right)$ 

DEVELOPMENT OF A DIGITAL MODEL OF GROUND-WATER FLOW IN

DEEPLY WEATHERED CRYSTALLINE ROCK, CHESTER COUNTY, PENNSYLVANIA

By Laurence J. McGreevy and Ronald A. Sloto

\section{ABSTRACT}

The model developed in this study simulates recharge to, flow through, and discharge from the water-table aquifer in the upper Pickering Creek basin, a 5.98-square-mile basin representative of most of Chester County, Pennsylvania. The two-dimensional finite-difference model of Trescott, Pinder, and Larson was used with slight modification. The way ground-water evapotranspiration varies with depth was modified, and a minimum transmissivity was used to prevent the model from "going dry" during water-table simulations.

Tests of the model showed good correlation with field data, but also showed that certain additional types of information would be useful to make the model more reliable. Particularly helpful would be more water-level and evapotranspiration data, synoptic base-flow measurements in the subbasins, and better information on the variation of permeability and specific yield with depth.

Predictive simulations made by the model show the effects of imposing various changes on the hydrologic system. Residential development was simulated in 1 square mile of the basin by combinations of the following conditions: 1-acre, 1/2-acre, and 1/4-acre lot size; wastewater disposal by septic systems or by public sewers; domestic wells or public-supply wells for water supply; and 0,1 , and 5 percent reduction in recharge in the developed area. Where water is supplied 1ocally by wells, decreased lot size and reduced recharge result in increased drawdowns and reduced base flow. When wastewater is exported by sewers, these effects are magnified. The simulations by the model show the relative severity of the effects of various development schemes. 


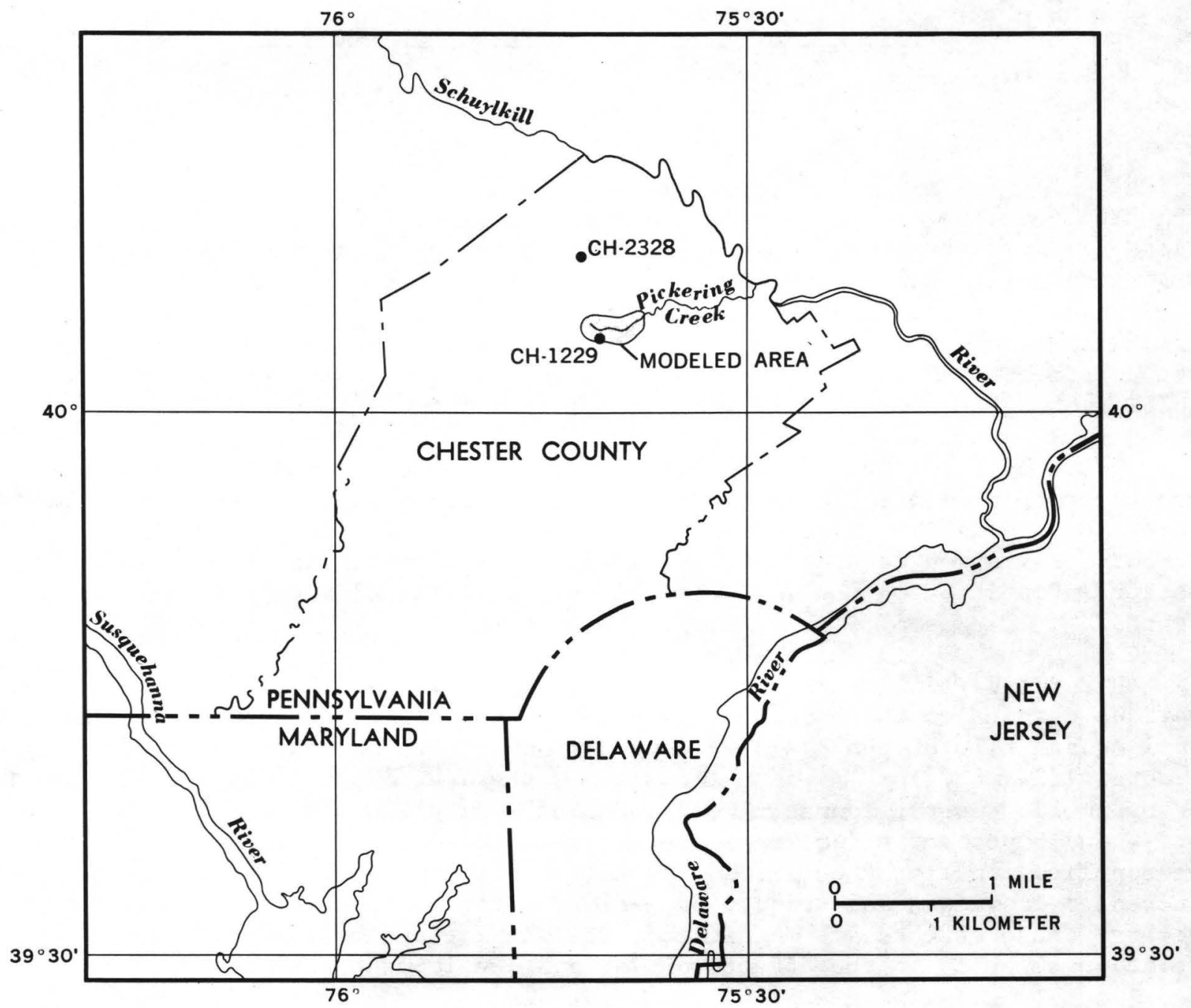

FIGURE 1.-- LOCATION OF MODELED AREA. 


\section{Purpose and Scope}

This report discusses the development of a computer model of groundwater flow in the deeply weathered crystalline rock of Chester County, Pa. The model was developed to provide a means for predicting effects of change on the local hydrologic system. The study was a followup to a study of the groundwater resources of the county (McGreevy and Sloto, 1977). Development of the model began in 1976 as a 2-year study by the U.S. Geological Survey in cooperation with the Chester County Water Resources Authority.

Many hydrologic studies had been done in Chester County, and a large amount of data were available. The model was developed from available data and that being collected in ongoing hydrologic data programs.

Modeling the entire county was impractical. Instead, the model was developed for a small basin that is representative of most of the county. This report discusses development of the model and illustrates its utilization as a predictive tool.

\section{Selection of Model Area}

The part of Pickering Creek basin above the stream-gaging station at Chester Springs, $\mathrm{Pa}$., was selected for the model. A considerable amount of hydrologic data are available for the basin, and hydrologic conditions are representative of most of Chester County.

The basin is in northern Chester County (fig. 1) at the headwaters of Pickering Creek, a tributary to the Schuylkill River. It has a drainage area of 5.98 square miles and is mostly undeveloped, being comprised of farmland and woodland and two small recently constructed residential subdivisions. The topography is characterized by gently rolling hills that range in altitude from 636 feet on the northern drainage divide to 280 feet at the stream gage. Precipitation averages 45 inches per year.

Continuous streamflow records since January 1967 are available for the gage at the mouth of the basin near Chester Springs (station 01472174). Miller, Troxe11, and Leopold (1971) made a detailed surface-water investigation in this basin and include many low-flow measurements in their report. Monthly water levels have been measured since 1974 at one well in the basin, and a continuous water-level recorder has been operating in an adjacent basin since 1975. Ground-water resources in the area are discussed by McGreevy and Sloto (1977).

\section{Local Hydrology}

The model discussed in this report represents hydrologic conditions in an area where noncarbonate crystalline rock is fractured and deeply weathered. Most of the modeled area is underlain by graphitic gneiss (fig. 2). Residual decomposed rock forms the soil and grades downward to unweathered rock. Most ground water is stored in and transmitted through a zone that consists of both decomposed rock and weathered fractured rock. A relatively minor amount of water moves through fractures in the deeper unweathered rock. 


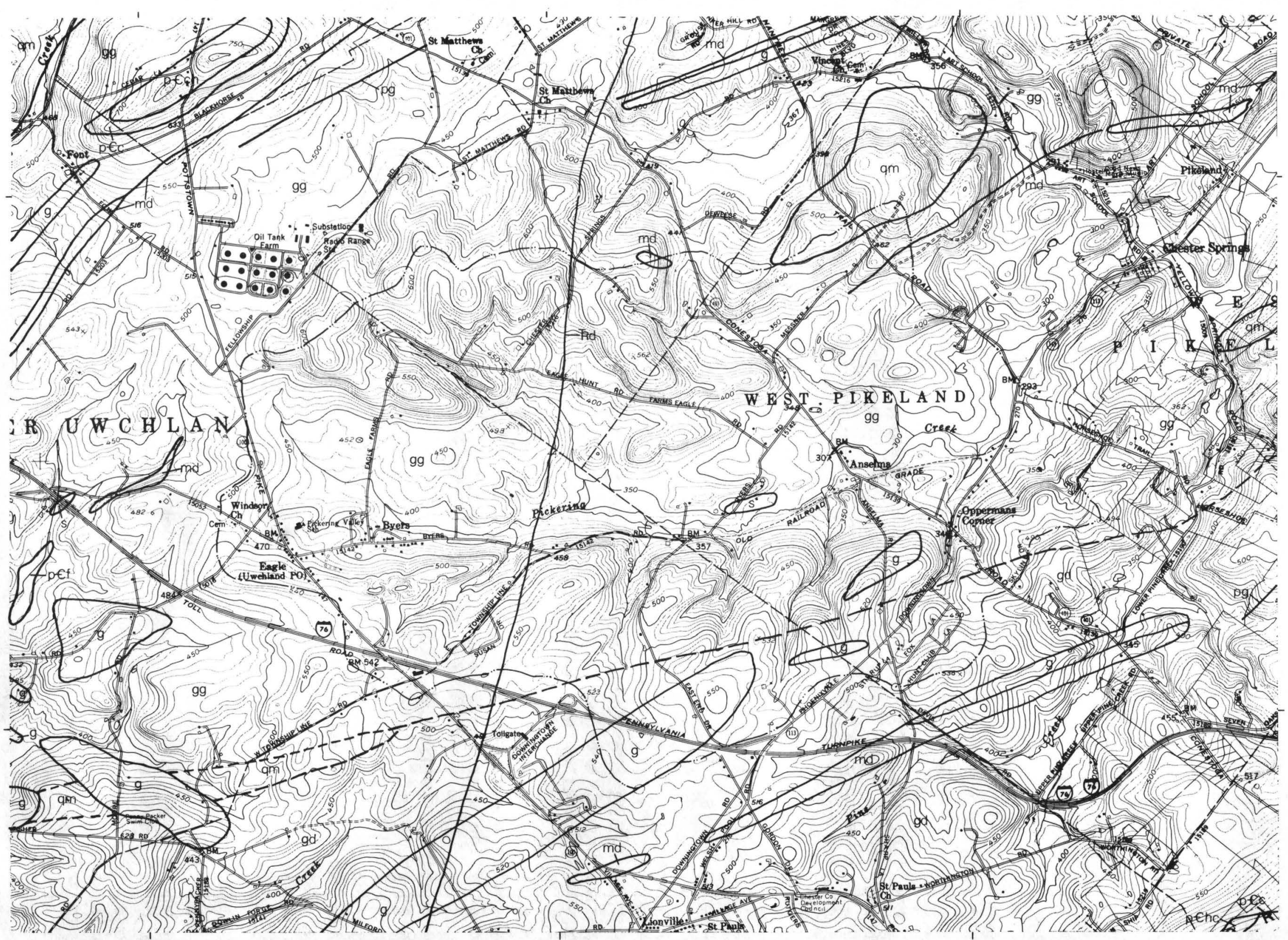

BASE FROM U.S. GEOLOGICAL SURVEY DOWNINGTOWN, 1:24,000, 1973, AND MALVERN, 1:24000, 1973.
CONTOUR INTERVAL 10 FEET

NATIONAL GEODETIC VERTICAL DATUM OF 1929
GEOLOGY MODIFIED FROM F. BASCOM AND G. W. STOSE, 1938

1 MILE 


\section{EXPLANATION}

\section{DESCRIPTION OF MAP UNITS}

$\mathrm{k} d$ DIABASE - Dikes and sills; medium-to-fine grained, dark-gray. Contact - Dashed where approximate.

p€c

Hellam Member at base of Chickies Quartzite Conglomerate, quartzite, sandstone, and schist; partly arkosic.

CKIES QUARTZITE - Quartzite, thin-bedded to massive, light-colored. Includes pure quartzite, micaceous quartzite with tourmaline crystals, quartzose schist, and sandstone.

METADIABASE - Dikes of altered diabase, mostly blueish-gray, some green.

PEGMATITE - Chiefly quartz and feldspar, coarsely-crystalline. Occurs both as dikes and as lenses which may be local variations of the county rock.

\section{S}

SERPENTINITE - Fibrous to massive magnesium-rich rock, mostly dark to light-green.

QUARTZ MONZONITE - Quartz monzonite or gneiss of similar composition, mostly medium-grained, gray.

GRANODIORITE - Grandiorite or gneiss of similar composition, mostly medium-grained; gray.

GABBROIC GNEISS AND GABBRO - Rocks of generally gabbroic composition; medium-grained, gray, green, brown and black.

FRANKLIN LIMESTONE - Coarsely crystalline white graphitic marble. Found only in small isolated lenses in the graphitic gneiss.
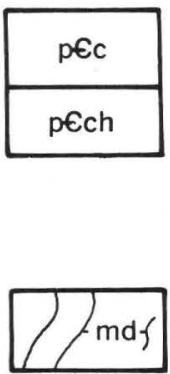

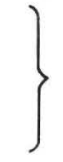

TRIASSIC

PRECAMBRIAN

GRAPHITIC GNEISS - Medium-grained gneiss and schist

characterized by the presence of graphite. Part of a metamorphosed sedimentary sequence that includes the Franklin Limestone.

(Has been called Pickering Gneiss)

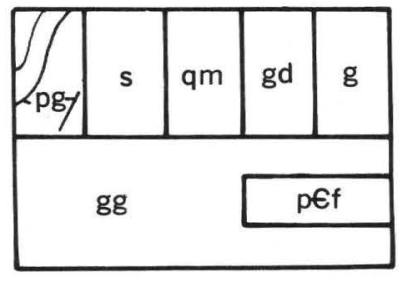

FIGURE 2.-- GEOLOGIC MAP OF MODELED AREA. 
Ground-water divides coincide closely with topographic divides, and streams are closely spaced. The distance from divide to stream is generally less than half a mile. Recharge to the ground-water system is from local precipitation. Discharge from the system provides base flow to adjacent streams; underflow to distant streams is not significant. In areas of shallow water table, part of the evapotranspiration derives directly from the ground-water system. However, most evapotranspiration derives from water held in the soil that did not reach the ground-water system. The local hydrology is discussed in more detail by McGreevy and Sloto (1977).

A map of the approximate water-table in the basin is shown in figure 3. Water-level measurements at 28 wells, reported levels at 7 other wells, and stream altitudes taken from a topographic map were used for control. The shape and altitude of the contours between control points were inferred from the topography. The map does not represent a single time, but is assumed to represent generalized conditions over a period of time. The amplitude of water-level fluctuations is genera1ly less than $10 \mathrm{feet}$, so this assumption is approximately correct.

\section{SIMULATION OF THE GROUND-WATER SYSTEM}

\section{Model Selection}

The upper Pickering Creek basin was modeled by the two-dimensional, finitedifference model of Trescott, Pinder, and Larson (1976) with slight modification. The mathematical background for the equations used to describe ground-water flow and the strongly implicit procedure (SIP) of finite-difference approximation, which is used to solve the equations, are described in detail by Trescott, Pinder, and Larson and are not repeated in this report. Modifications to the model are described in the sections of this report that discuss the appropriate parameters. The modifications concern a change in the way ground-water evapotranspiration varies with depth to water and the use of a minimum transmissivity and alternate specific yield. In addition, output was modified to provide maps of depth to water, leakage to streams, and base flow.

The basin is represented as a layer of cells defined by a grid, as shown in figure 4. An average value for each aquifer parameter for each cell is assigned to a node at the center of the cell. Recharge, ground-water evapotranspiration, and pumping are introduced at appropriate cells. The model then calculates the resulting inflow and outflow to adjacent cells, leakage to or from streams, and the resulting heads. 


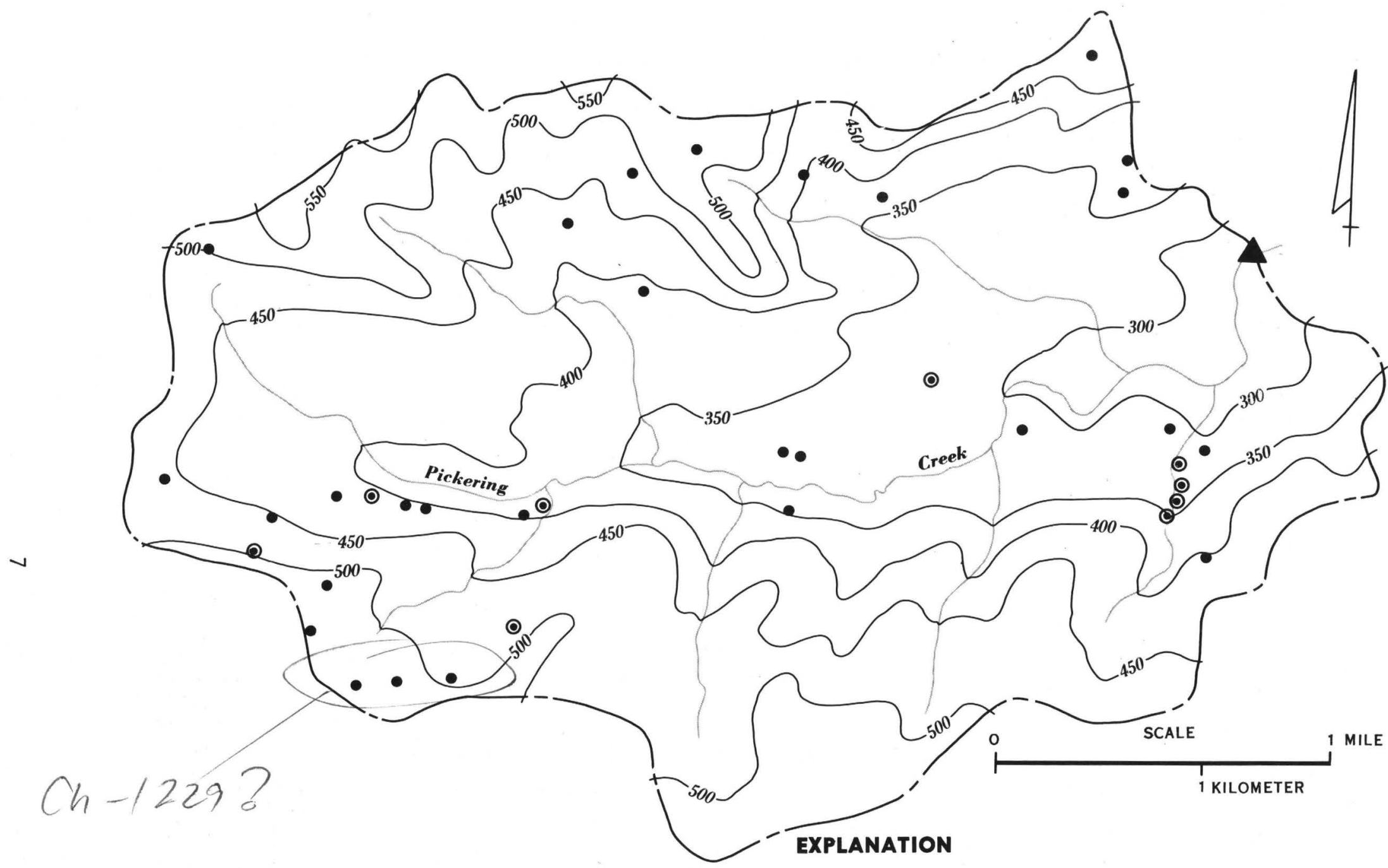

- 500 WATER-LEVEL CONTOUR - Shows approximate altitude of the potentiometric surface of the ground-water system. Shape and altitude inferred from topography, streams, and water-level

- WELL USED FOR CONTROL - Measured water level.

O WELL USED FOR CONTROL - Reported water level.

- Surface WATER Gaging Site 01472174

- - DRAINAGE BASIN BOUNDARY 


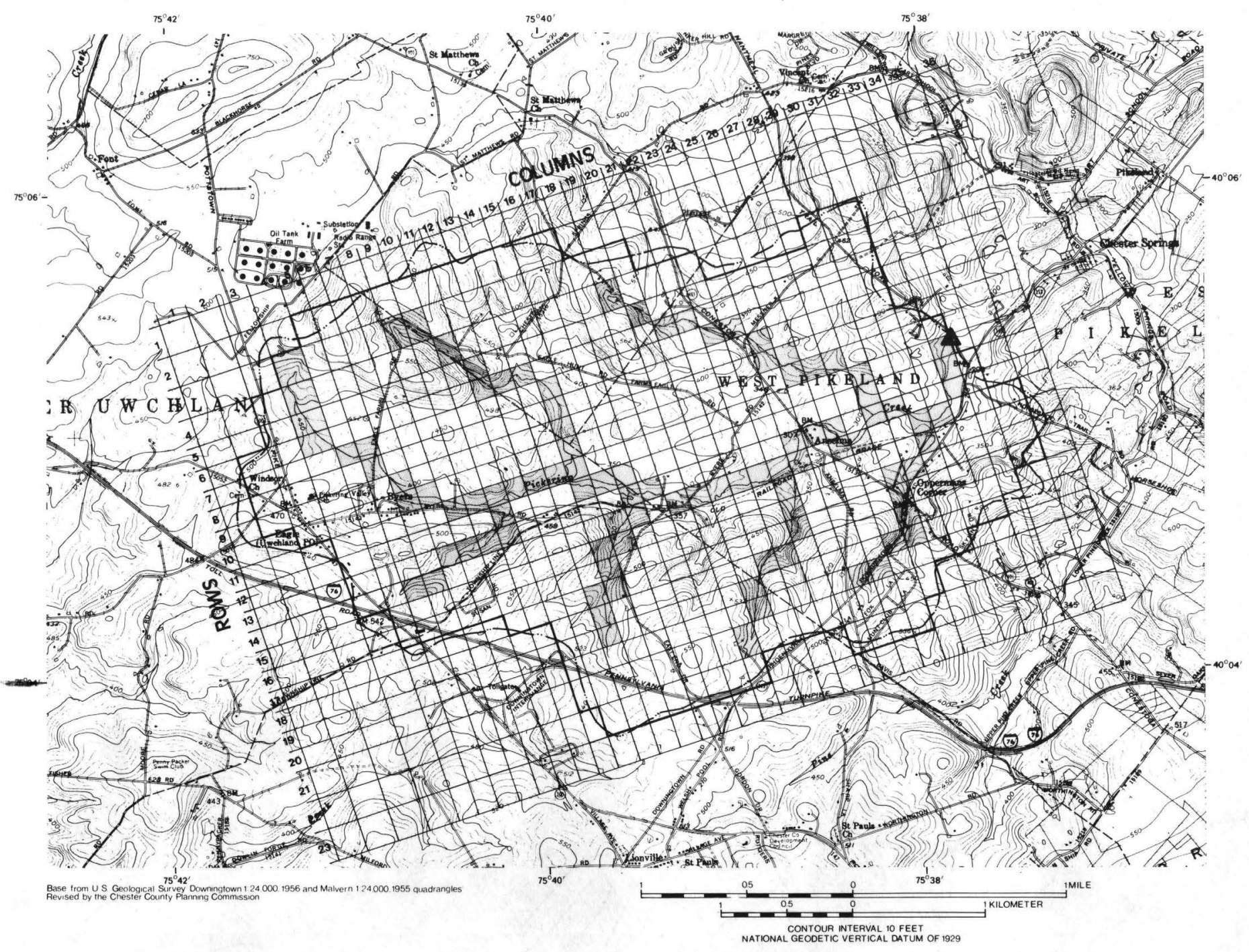

EXPLANATION

-... BASIN BOUNDARY

SIMULATED BASIN BOUNDARY

STREAM CELLS

A Surface water Gaging SITE 01472174

FIGURE 4. -- FINITE-DIFFERENCE GRID. 
The general pattern of model development is outlined in this section. Further details on the estimation of individual parameters and the testing of the model are given in subsequent sections.

The initial steps were undertaken with a simple linear model that represents a typical or generalized line of section along the path of ground-water flow from the drainage divide to the stream. This simple model is effectively one node wide and nine nodes long along the line of section. Procedures for estimating parameters and methods of calibration and testing were first worked out with the linear model. When the procedures were established, they were used in constructing and calibrating the areal model of the full basin. The six general steps in model development are outlined below.

1. A steady-state version of the linear model was constructed and calibrated. Initial values of transmissivity were obtained by the method discussed in the section on transmissivity. Recharge was applied evenly to the area of the model as a recharge rate. The total recharge applied was taken as equal to the ground-water contribution to stream base flow from the area represented by the model on August 20, 1975. (The steady-state simulation sets up initial conditions for a transient simulation that begins on this date.) Base-flow estimates were based on streamflow records for the Pickering Creek gaging station. The model computes the groundwater discharge to the stream, which is essentially equal to base flow in the study area. (See section "Leakage to and from streams.") Transmissivity values were refined during calibration to achieve agreement with the water-level distribution along the typical line of section represented by the linear model.

2. A nonequilibrium, or transient version of the linear model was constructed and tested. Initial conditions were those of the steady-state calibration, step 1. This model utilized hydraulic conductivity and saturated thickness to calculate transmissivity at each time step. Values of hydraulic conductivity were estimated by a method utilizing an assumed general relation between the steady-state transmissivity and the hydraulic conductivity in the upper part of the saturated interva1. (See section "Hydraulic Conductivity and BOTTOM.") This relation was modified several times during calibration, until a relation was found that gave hydraulic conductivities that yielded satisfactory results during the transient simulation.

Specific yield was initially taken to be 0.08 throughout the modeled area based on estimates in other similar areas. (See section "Specific Yield and Storage Coefficient.") Variations of this value to 0.06 and to 0.10 caused poorer model results, and the value of 0.08 was, therefore, retained. 
The transient test covered the period from August 20, 1975, to December 31, 1976. This period was broken into 200 segments of 1 to 6 days. Recharge values were fed into the model for each segment. (Recharge was determined as discussed in the section "Recharge.") Water-level fluctuations of the model agreed closely with observed fluctuations in a representative observation well. Base flows from the model agreed with baseflow estimates from streamflow data during the nongrowing season, but during the growing season, base flows from the model were consistently too high.

This indicated that, during the growing season, a significant amount of ground water was being discharged directly from the water table to the atmosphere through evapotranspiration (ET). Consequently, to achieve agreement with seasonal variations in base flow, the linear model had to be recalibrated incorporating ground-water ET.

3. The steady-state calibration of the linear model, step 1 , was repeated incorporating ground-water ET. The amount of groundwater ET computed by the model depends on the maximum ET rate (QET) and the depth to the water table, as discussed in the section "Evapotranspiration from the Water Table." An estimated average value for QET of 1 foot per year was used for the steadystate calibration. Total recharge applied to the model equaled the base flow, as in step 1, plus the ground-water ET. (QET times the area of shallow water table in the model gave an initial estimate of ground-water ET. Recharge was adjusted further until the model computed the appropriate base-flow value.) Initial values of transmissivity were again refined to achieve agreement with the water-level distribution along the typical line of section represented by the linear model.

4. Construction and testing of the transient version of the linear model, step 2, was repeated incorporating ground-water ET. Initial conditions were those of the steady-state calibration, step 3, and a11 of the procedures and assumptions of step 2 were repeated. The model program computes the amount of ET based on the maximum ET rate (QET) and the depth to the water table, as discussed in the section "Evapotranspiration from the Water Table." Several sets of QET values were tried to obtain seasonal variations in base flow from the model that agreed with base flow estimated from streamflow data. Adequate results were obtained with rates of 3 feet per year for May-August, 1-1/2 feet per year for September-November, and zero for December-April. Water-level fluctuations of the model still agreed closely with observed fluctuations in a representative observation well. 
5. A steady-state version of the areal model of the Pickering Creek basin was constructed and calibrated. The procedures established in step 3 were followed. A QET estimate of 1 foot per year was used. Total recharge was equal to the ground-water ET plus the base flow at the Pickering Creek gage for August 20, 1975. (QET times the area of shallow water table gave an initial estimate of the ground-water ET, as in step 3. Recharge was adjusted further until the model computed the appropriate base-flow value.) Total recharge was applied evenly as a recharge rate. Initial transmissivity values were obtained by the method discussed in the section "Transmissivity," and the recharge rate determined as above. Transmissivity values were then refined during calibration until the head distribution calculated by the model was in satisfactory agreement with the approximate water-table map (fig. 3). The distribution of base flow within the basin, as computed by the steady-state model, was consistent with measurements as discussed in the section "Testing the Model."

6. A transient version of the areal model of the Pickering Creek basin was constructed and tested. Initial conditions were those of the steady-state calibration, step 5, and the procedures established in step 4 were followed. Values of hydraulic conductivity were estimated by the method outlined in the section "Hydraulic Conductivity and BOTTOM." A specific yield of 0.08 was used throughout the modeled area. Maximum ET rates (QET) were 3 feet per year for MayAugust, 1-1/2 feet per year for September-November, and zero for December-April. The transient test covered the period August 20, 1975, to December 31, 1976, and was broken into 200 segments, as in step 4. Recharge rates and QET were put into the model for each segment, and base flows and water levels were produced by the model for each segment.

Tests of the model described in the section "Testing the Model," showed good correlation with base-flow and water-level

fluctuation.

\section{Boundary Conditions}

In the modeled area, ground-water drainage divides between streams are at approximately the same location as the surface-water drainage divides. Under natural conditions, a drainage divide is a no-flow boundary; water from one side of a divide does not move across the boundary to the other side. The drainage divide of the upper Pickering Creek basin is approximated in the model at cell boundaries, as shown on figure 4. Zero transmissivity or hydraulic conductivity is assigned to cells outside of the boundary. This allows no flow across the boundary in the model and defines the active model cells.

Under present conditions the drainage boundary is stable. However, if simulated pumping or artificial recharge causes drawdown or rise of the water level at a cell adjacent to the boundary, then the assumption of no flow may no longer be valid. 
Hydrologic parameters used in the model of the upper Pickering Creek basin are listed in table 1. The following sections tell how they are used.

Table 1.--Hydrologic parameters used in the model

$\begin{array}{ll}\text { STRT } & \text { Water-level altitude at start of simulation } \\ \text { T } & \text { Transmissivity } \\ \text { S } & \text { Storage coefficient } \\ \text { PERM } & \text { Hydraulic conductivity } \\ \text { BOTTOM } & \text { Represents the altitude of the base of the aquifer. (See discussion.) } \\ \text { SY } & \text { Specific yield } \\ \text { TOP } & \text { Minimum transmissivity for water-table simulations } \\ \text { RATE } & \text { Surface area of stream within cell divided by the area of the cell } \\ \text { M } & \text { Reciprocal of the leakage-characteristics factor. (See discussion of } \\ & \text { leakage.) } \\ \text { RIVER } & \text { Altitude of the stream surface } \\ \text { GRND } & \text { Mltitude of the land surface } \\ \text { QET } & \text { Depthum rate of ground-water evapotranspiration water above which evapotranspiration rate = QET } \\ \text { ETFULL } & \text { Depth to water below which evapotranspiration rate }=0 . \text { Rate decreases } \\ \text { ETDIST } & \text { linearly as the depth to water increases from ETFUL to ETDIST. } \\ \text { QRE } & \text { Recharge rate } \\ \text { WELL } & \text { Pumping rate }\end{array}$

Transmissivity

Initial transmissivity values for use in the model were estimated from Darcy's law. Transmissivity at a particular location was related to the amount of water moving downgradient past that location and to the slope of the water table across the location (fig. 5). Using these transmissivity values, the model program calculated a corresponding head distribution over the model area at steady state. This distribution was compared with heads determined from the map of the approximate water table of the area (fig. 3). (To facilitate interpolation, a version of the water-table map with 10-foot contours was used to estimate heads for comparison.) Transmissivity values were adjusted (calibrated) until a satisfactory head distribution was calculated by the model. Agreement within 10 feet was considered satisfactory since the water-table map itself was subject to errors that might be greater than 10 feet.

Transmissivity values at nodes nearest a stream were adjusted first, because transmissivity values at downgradient nodes affect water levels at upgradient nodes. Adjustment then proceeded upgradient toward the drainage divide. The location of subbasin drainage divides within the model is critical and must be checked for each adjustment run. An improper transmissivity value in one or two nodes can cause a head distribution that improperly locates a subbasin drainage divide. This may change the drainage pattern and affect water levels in a large section of the model. 


\section{SECTION VIEW}

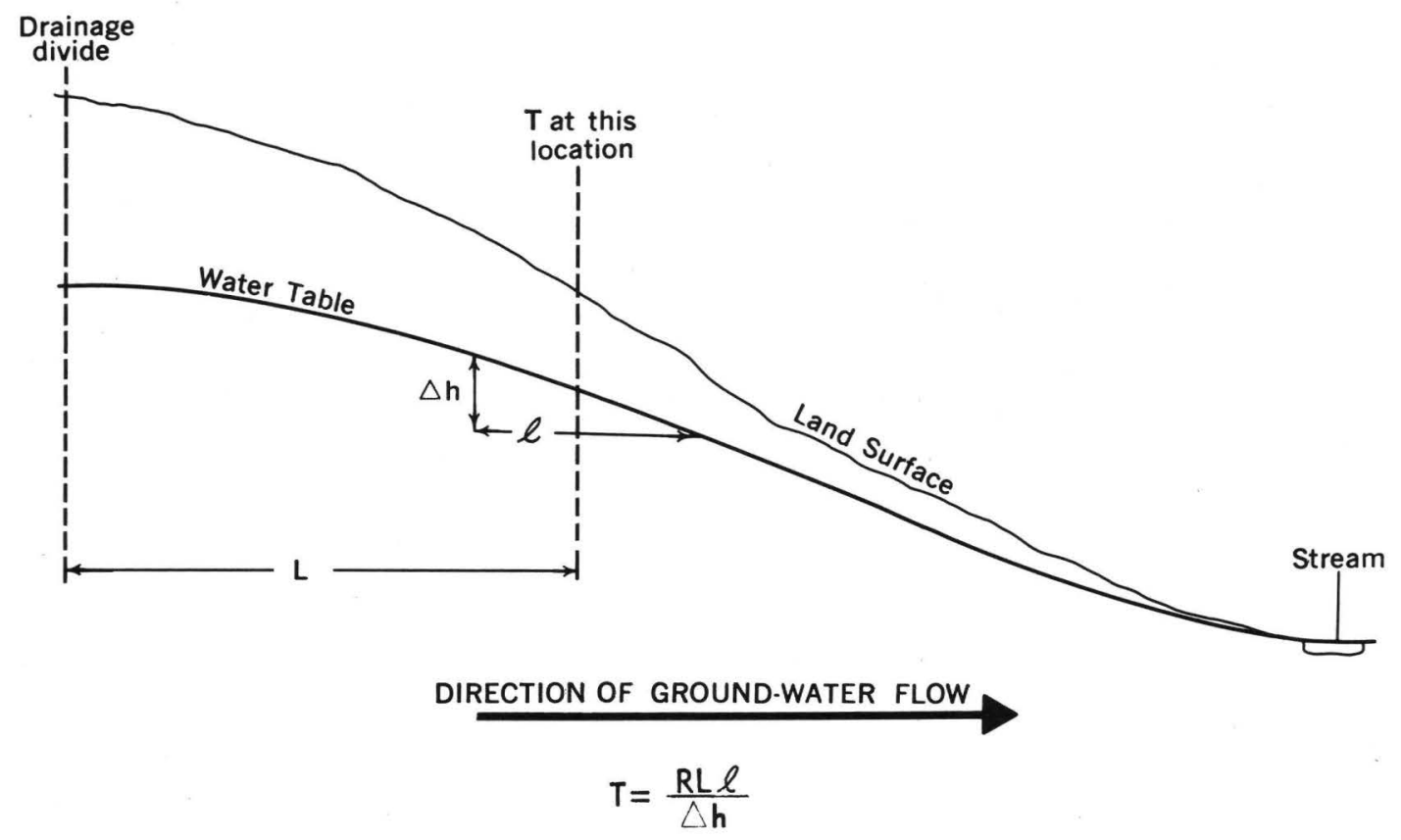

WHERE:

T= TRANSMISSIVITY AT A PARTICULAR LOCATION

$\mathrm{R}=$ RECHARGE RATE

$L=$ DISTANCE FROM DIVIDE TO LOCATION

$\triangle h=$ CHANGE IN HEAD OVER DISTANCE $l$

FIGURE 5. .- METHOD OF ESTIMATING INITIAL TRANSMISSIVITY VALUES. 
Subbasin drainage divides may be inferred from the water-table map (fig. 3) and from the topography (fig. 4). (The water table in the Pickering Creek area is generally related closely to the topography.) Maintenance of proper drainage patterns and subbasin divides is an important constraint on the head distribution of the model and thus on the calibration of transmissivity.

Figure 6 shows the transmissivity values used in the final steady-state calibration run. Values ranged from $5 \times 10^{-5}$ to $2 \times 10^{-2} \mathrm{ft}^{2} / \mathrm{s}$, or about 4 to $1700 \mathrm{ft}^{2} / \mathrm{d}$. The values compare favorably with transmissivity estimates for 18 pumping tests in gneissic rock of Chester County, which range from about 6 to $1100 \mathrm{ft}^{2} / \mathrm{d}$. (See McGreevy and Sloto, 1977, p. 1819.)

The higher transmissivity values occur in draws or valleys where most of the more permeable weathered zone is saturated. (See section "Local Hydrology.") Also, such topographic lows are of ten related to linear features that may indicate weaker zones in the rock and presumably zones of higher than average intensity of fracturing and weathering.

Hilltop cells that represent drainage divides may have transmissivities that are lower than valley cells by as much as two orders of magnitude. These cells represent areas where most of the weathered zone is unsaturated and where fracturing is less intense.

Hydraulic Conductivity and BOTTOM

The model program was operated in a water-table mode during all transient simulations. In this mode, the program calculates a transmissivity at each node for each time step using the relation

$$
\mathrm{T}_{i j}=\mathrm{k}_{i j}\left(\mathrm{~h}_{i j}-\text { вотTOM }_{i j}\right) \text {, }
$$

where

$$
\begin{aligned}
& \mathrm{T}_{i j}=\text { Transmissivity at node } i j \\
& \mathrm{k}_{i j}=\text { Hydraulic conductivity at node } i j \\
& \mathrm{~h}_{i j}=\text { altitude of head at node } i j
\end{aligned}
$$

and BOTTOM $_{i j}{ }^{i}$ Fepresents the altitude of the base of the aquifer at node $i j$.

This formula assumes that hydraulic conductivity is constant with depth. In the study area, hydraulic conductivity normally varies with depth and becomes very small below the weathered zone. The model program can be used effectively, however, as long as the water table itself remains in an interval where hydraulic conductivity is approximately constant with depth. In the study area, the interval of normal water-table fluctuation has a fairly narrow range of depth, and in this interval, the change of hydraulic conductivity with depth is generally small. For the simulations of this study, the hydraulic conductivity of this interval was assumed to be constant.

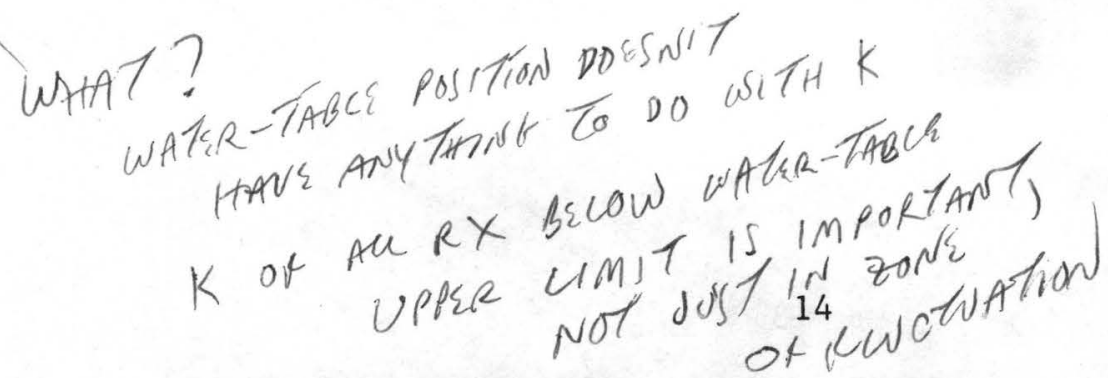




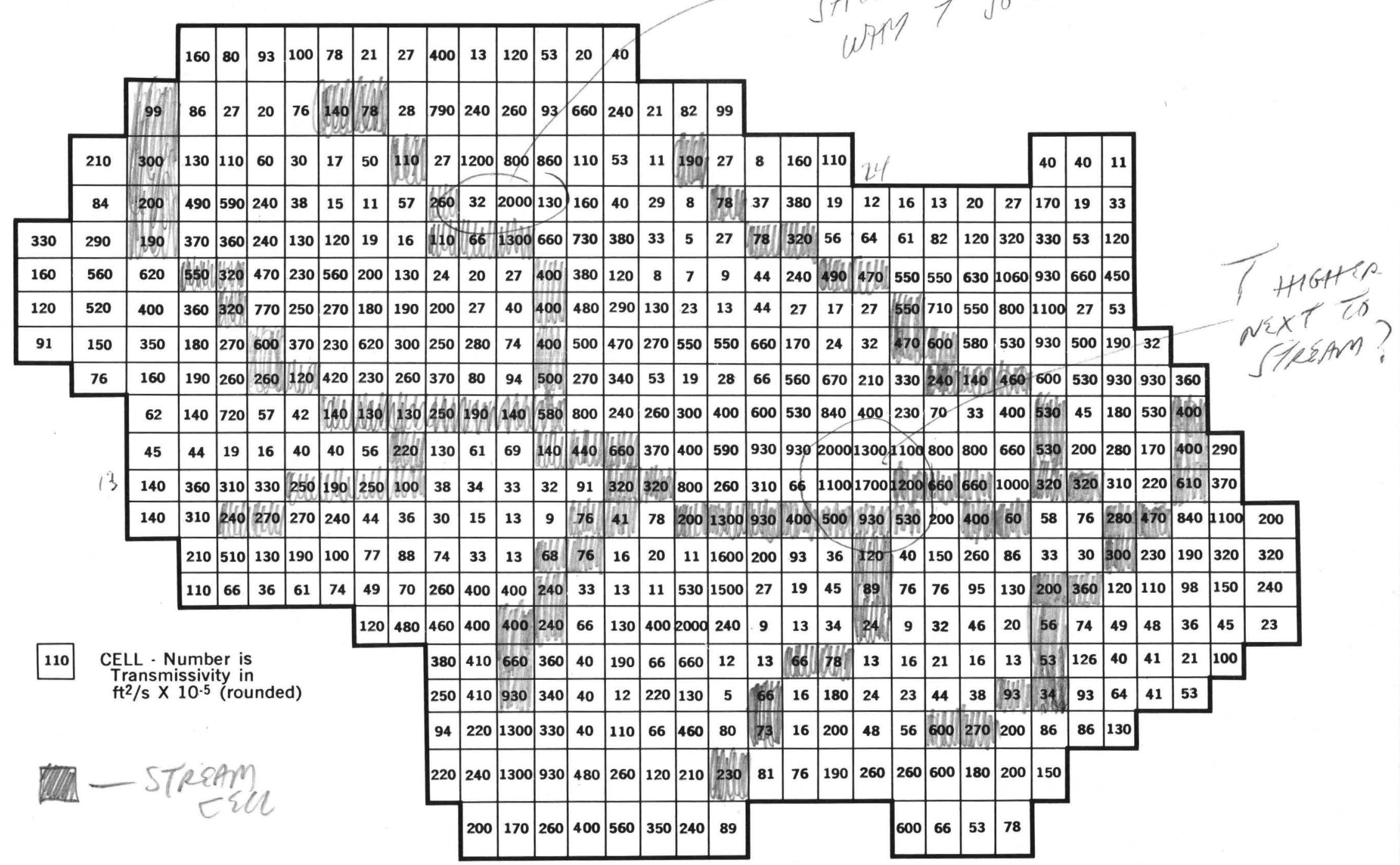

FIGURE 6.-. TRANSMISSIVITY VALUES USED IN THE FINAL STEADY-STATE CALIBRATION RUN. 
As water-level change, $\Delta h$, takes place during transient simulation in the water-table mode, the values of $\mathrm{T}_{i j}$ must be changed by a value $\mathrm{k}_{i j} \Delta \mathrm{h}_{i j}$, where $\mathrm{k}_{i j}$ designates the hydraulic conductivity within the interval of ${ }^{2}$ water -1 evel change. Inltial conditions for the transient simulation were those of the steady-state calibration. Thus, values of $\mathrm{k}_{i j}$ (PERM matrix) and BOTTOM ${ }_{i j}$ (BOTTOM matrix) were specified that, when combined in equation (1) with the values of $h_{i j}$ from the steady-state calibration, gave $\mathrm{T}_{i j}$ values that were the same as those of the steady-state calibration. Because values of $k_{j}$ used in the PERM matrix represent the interval of water-table fluctuation instead of the entire saturated interval, as assumed by equation (1), the concept of BOTTOM had to be adjusted accordingly. That is, values inserted in the BOTTOM matrix were not the actual base of the aquifer, but were the numbers required to generate the correct initial transmissivities. Values inserted for each node were calculated from the relation

$$
\text { воттом }_{i j}=\mathrm{h}-\frac{\mathrm{T}_{o i j}}{\mathrm{k}_{i j}},
$$

where $\mathrm{h}_{i j}$ and $\mathrm{T}_{i j}$ are the water-table altitude and transmissivity, respectively, of the steady-state calibration and $k_{i j}$ is the estimated hydraulic conductivity for the zone of water-table fluctuation. It should be clear that the values of BOTTOM have no particular physical significance in terms of the actual base of the aquifer, but are artificial terms created to obtain a reasonable simulation without reprogramming the model.

The method of estimating the hydraulic conductivity values for the PERM matrix is based on the assumption of a consistent relation between hydraulic conductivity and transmissivity. Previous studies of the area have established that transmissivity generally increases from the divide areas to the stream valleys. The increase is due in part to an increase in hydraulic conductivity and in part to an increase in saturated thickness. Thus, one would expect the hydraulic conductivity of the zone of water-table fluctuation to be higher in areas of high transmissivity and lower in areas of low transmissivity, although the relationship, in general, would not be linear or even the same throughout the modeled area. However, to facilitate the estimation of hydraulic conductivity, a consistent relation between transmissivity and the hydraulic conductivity of the zone of water-table fluctuation was assumed throughout the area. The assumed relation is shown by the line in figure 7. Clearly, other relations could have been assumed, and in fact, others were tried during the course of model development. The relation shown in figure 7 gave hydraulic conductivity values that were consistent with lithologic data and gave good results in transient tests of the mode1.

The values of hydraulic conductivity used in the PERM matrix of the model were read from figure 7. They ranged from $2.6 \times 10^{-6}$ to $1.1 \times 10^{-4} \mathrm{ft} / \mathrm{s}$, which is consistent with a soil survey of the area (Kunkle, 1963, table 6) that reported values from less than $4.6 \times 10^{-6}$ to $1.4 \times 10^{-4} \mathrm{ft} / \mathrm{s}$. 


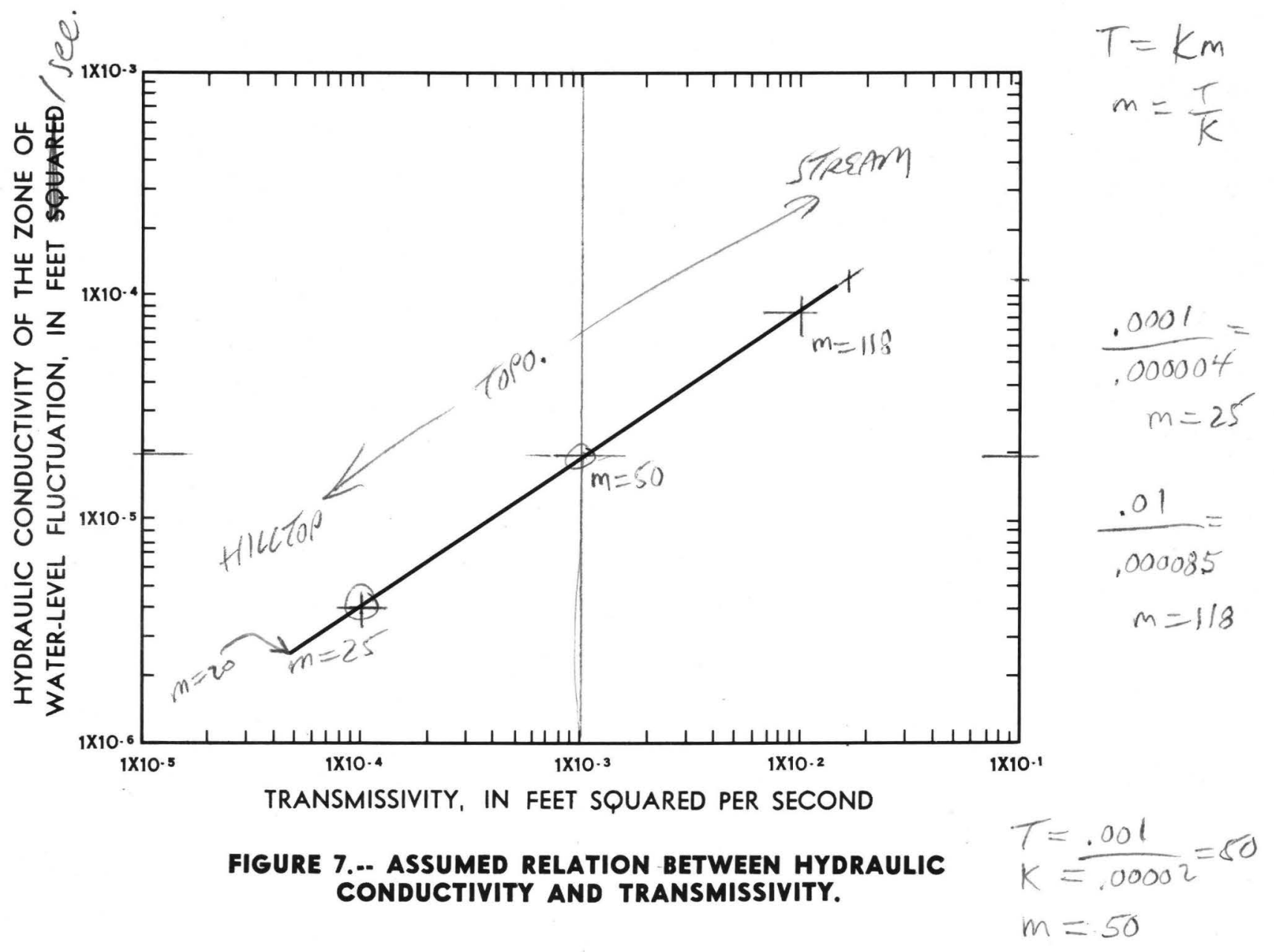

Minimum Transmissivity

On some hilltops or hillsides where transmissivities are very low, the water table may occur in relatively unweathered rock having very low hydraulic conductivity. In such areas, the water table may be visualized as lying near the bottom of the zone of principal ground-water flow. Fluctuating water levels at nodes representing such areas in the model may drop below the level representing the base of the aquifer (BOTTOM matrix). In reality, such water levels have merely dropped into a part of the aquifer system having different characteristics. To handle such situations and to prevent the model from "going dry" at such nodes, a minimum transmissivity was assigned for each node. (The model program was modified to store the minimum transmissivity values in the TOP matrix.) Whenever the transmissivity computed by the model program becomes less than the assigned minimum value, the minimum is used in the ground-water flow calculations. The lowest transmissivity of the calibrated steady-state run, $5.0 \times 10^{-5} \mathrm{ft}^{2} / \mathrm{s}$, was used as the minimum transmissivity for all nodes. 
Specific Yield and Storage Coefficient

Olmsted and Hely (1962) estimated the gravity yield (short-term specific yield) in the adjacent Brandywine Creek basin to be between 0.075 and 0.10 . The specific yield in an area of similar rocks in York County, Pennsylvania, was calculated by Lloyd and Growitz (1977) to be 0.08, and the gravity yield in another similar area in the Maryland Piedmont was estimated by Nutter and Otton (1969) to be 0.08. Experimental runs with the linear model showed that a specific yield of 0.08 gave the best results.

The model program uses either the SY or the S matrix for the storage characteristic of the aquifer. For simulations using the transmissivity matrix, the $\mathrm{S}$ matrix is used. For those using hydraulic conductivity and BOTTOM to calculate transmissivity, the SY matrix is used unless the calculated transmissivity is less than or equal to the minimum transmissivity designated by the TOP matrix. In this special case, the value for that node in the $S$ matrix is used. This gives the opportunity to use an alternate storage value in conjunction with minimum transmissivity. Data for calibrating an alternate storage value were not available, however, and a value of 0.08 was used for both $\mathrm{S}$ and SY matrices.

\section{Leakage to and from Streams}

Under normal conditions in most of the modeled area, the head of the groundwater system is above the stream head and ground water leaks into the stream. Where conditions are reversed, the stream will leak into the ground-water system.

The handling of leakage in the model program is based on the concept of vertical flow through a restrictive layer separating the aquifer and stream. In the modeled area, leakage from the aquifer to the stream is probably controlled primarily by the vertical flow characteristics of the aquifer itself rather than by a restrictive layer. To use the program, a leakage factor was determined that incorporates the leakage controls, whatever their nature.

A leakage factor could not be measured directly, so it was estimated by observing its effects. In steady-state simulations, where total leakage is set by the input data, the ground-water head at stream nodes depends on the leakage factor. Small changes in leakage factor produced relatively large changes in head. The leakage factor, which was selected for use in the final model, gave reasonable heads of a few feet above the stream nodes in the basin model. WHY NOT US "RATL" MATRIX ROR LAFC. FAC.? heads

The M matrix is used for the leakage factor, but, because of the way the matrix is handled in the program, the inverse of the leakage factor is coded. An $\mathrm{M}$ value of $1.615 \times 10^{4} \mathrm{~s}$ was used. (This would be equivalent to a true restrictive layer 1 foot thick with a vertical hydraulic conductivity of $\left.6.19 \times 10^{-5} \mathrm{ft} / \mathrm{s}.\right)$

Leakage is also proportional to the stream-bed area. The area is defined

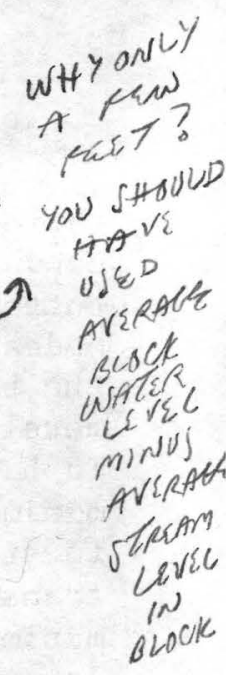
by the matrix called RATE which gives the ratio of streambed area within a cell to the total cell area. This matrix is also used to designate the stream nodes. The estimated surface areajof the stream in a cell divided by the area of the cell is assigned for each stream node. Values at all nonstream nodes are made equal to zero to distinguish them from the stream nodes.

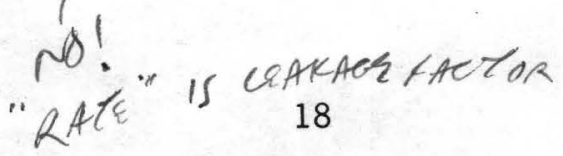


The stream head is defined in the model by the matrix called RIVER. The value assigned to RIVER for a particular node is the average of the lowest stream altitude of that cell and the lowest stream altitude of the next upstream cell.

\section{Land Surface Altitude} AVERAOL LSD + WATER VEVEC

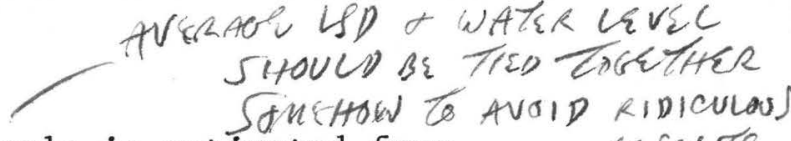

The average land-surface altitude for each node is estimated from pus topographic maps and is defined by a matrix called GRND. It is used to compute pe/t depth to water and evapotranspiration of ground water. For stream nodes, the trot altitude used in the RIVER matrix is used.

\section{Evapotranspiration from the Water Table}

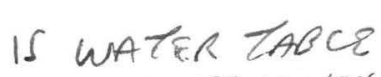

The model program computes the amount of evapotranspiration (ET) from the water table based on the maximum ET rate, QET, and the depth to the water table. It is a generalization of the method of Trescott, Pinder, and Larson (1976). Figure 8 shows the relation of ET rate to depth to the water table used in this study and compares it to that used by Trescott, Pinder, and Larson. The rate is assumed to be the maximum value, QET, whenever the simulated water level is above the depth designated by ETFULL. The rate decreases linearly as the water level drops from ETFULL to ETDIST and becomes zero at ETDIST. This relationship approximates the relation of the evaporation rate of soils to depth to water described by Ripple, Rubin, and van Hylckama (1972, figs. 7 and 8). For the simulations of this study, ETFULL was assumed to be 4 feet and ETDIST 5 feet.

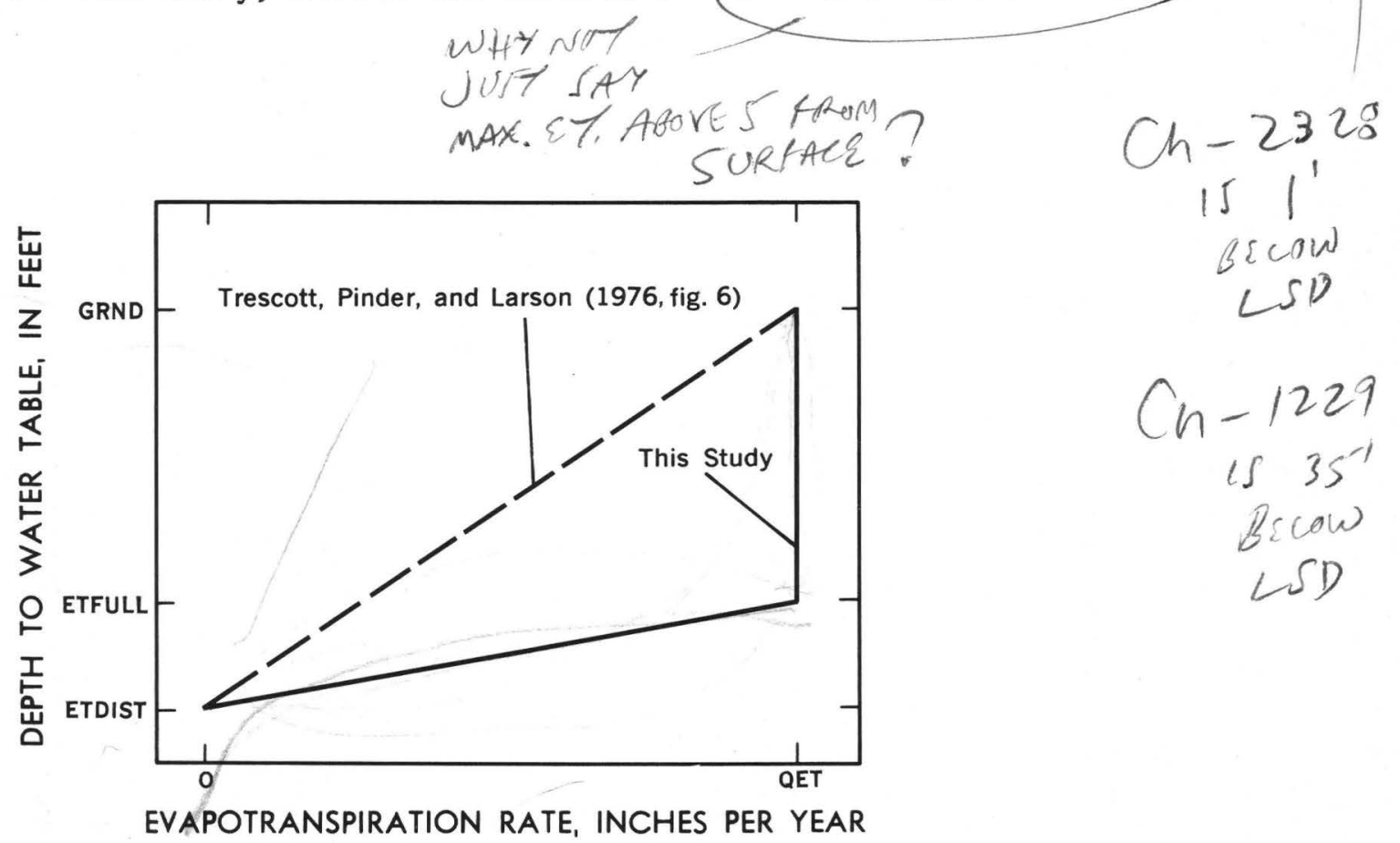

\section{FIGURE 8. -- RELATION OF GROUND-WATER EVAPOTRANSPIRATION RATE TO DEPTH OF THE WATER TABLE USED IN THE MODEL.}




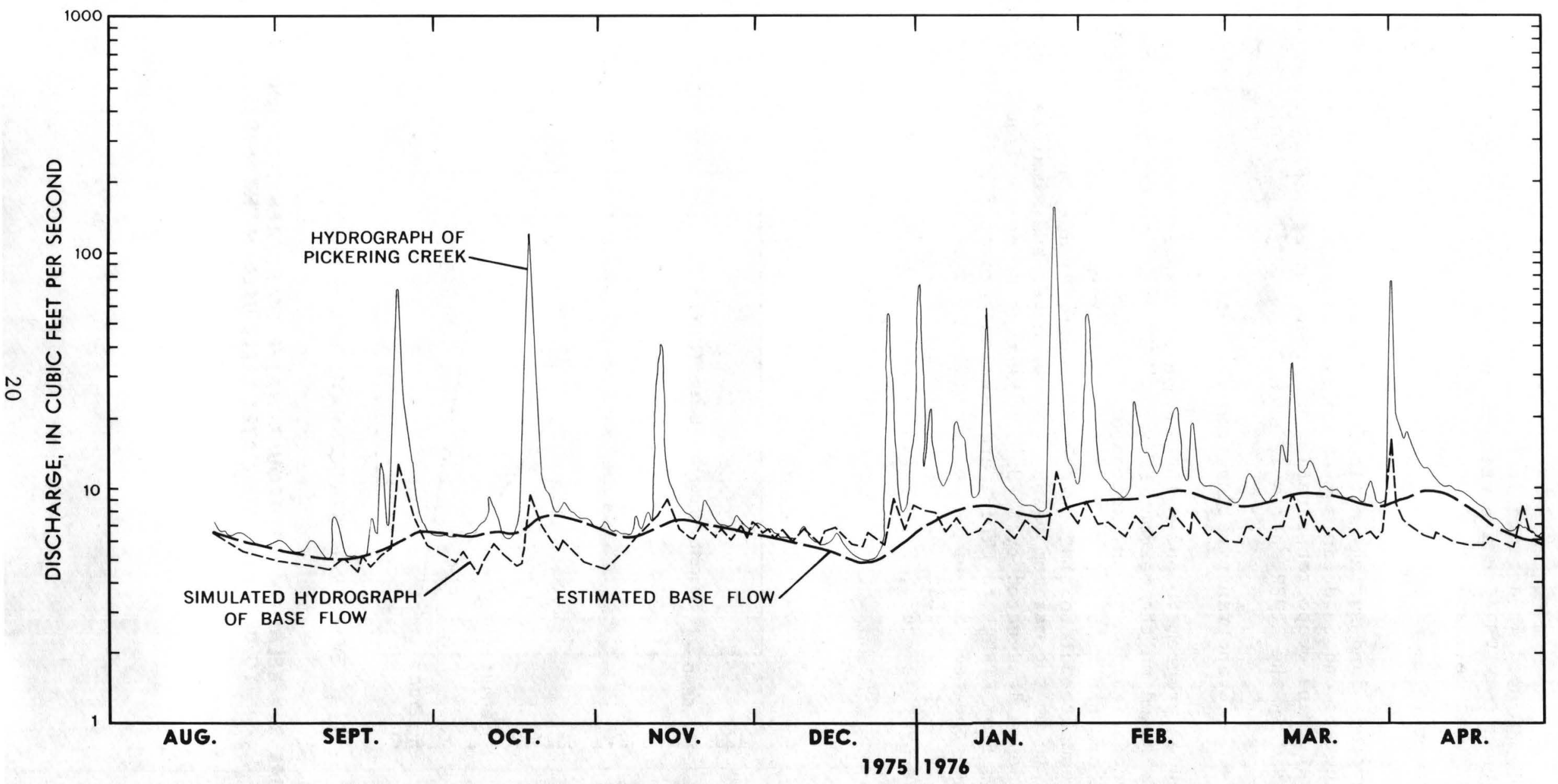




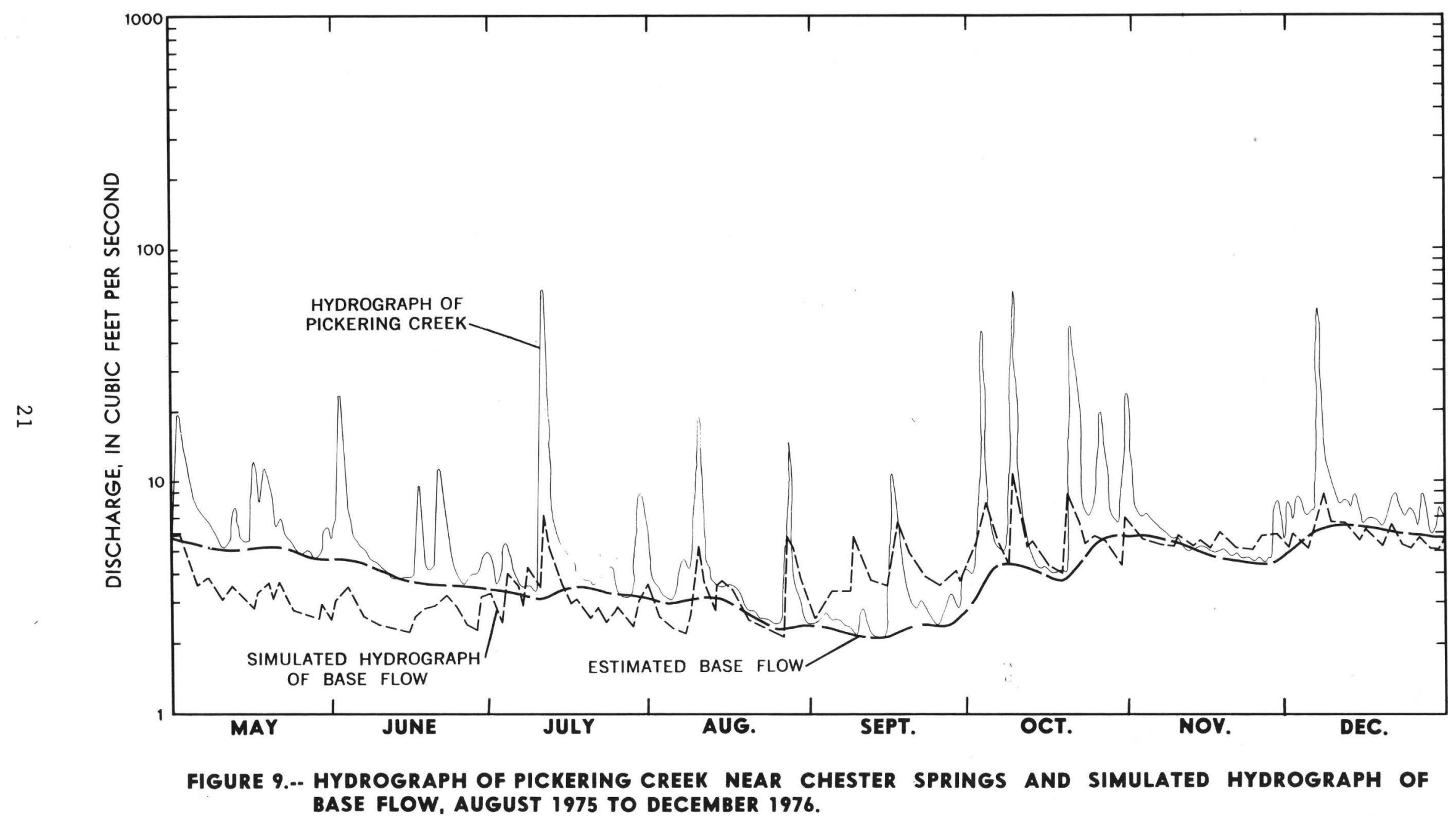


Ground-water ET rates in the basin have not been measured. The nearest panevaporation station is at Landisville, Pennsylvania, about 40 miles west of the modeled area. Transient simulations were made using different percentages of the daily pan-evaporation rate as QET. Simulations using rates of one-half and threefourths the pan-evaporation rate produced base flows that were near the estimated base flows for parts of the year, but neither set of rates was really satisfactory. It was evident that the variation in pan-evaporation rate at Landisville was not directly related to the variation in ground-water ET rate in the upper Pickering Creek basin., OR THAT ET WAT NOT THE CAUS OF THE DiJCRepaficis) (THS is covipep in
OET used in steps 4 and 6 of the mode

The estimated average values of QET used in steps 4 and 6 of the model development gave generally better results than the pan-evaporation data. These estimates were not refined, however, because they could prejudice the results. (If other variables were not in question, the model could theoretically be used to determine ground-water ET by adjustment of values until the proper base flow was obtained.)

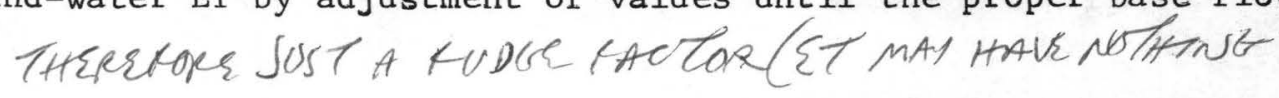

Figure 9 shows the hydrograph of base flow generated by the basin model compared to the observed stream hydrograph and estimated base flow. Base flow could be simulated much more accurately if the actual daily values of QET were known.

\section{Recharge}

Except for the predictive runs that simulate reduced recharge in developed areas, recharge was assumed to be evenly distributed and to occur simultaneously throughout the modeled area. THIS MAY BS MoR2 (MPOR TAN! TO ACCURACE MATCA OF GASECCOWT THAN ET

For steady-state runs, recharge was set equal to the amount of base flow plus estimated ground-water ET. (See discussion of model-development procedures.) Transient simulations require periodic recharge. These were estimated from evaluation of water-level hydrographs by a method similar to that of Rasmussen and Andreasen (1959, p. 94).

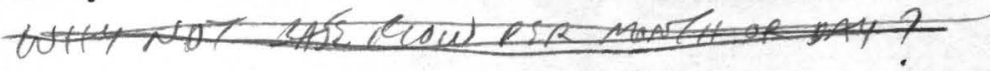

Ground-Water Pumpage

Pumpage from wells is handled in the model by extracting from each cell the amount of pumpage that is not returned to the ground-water system within the cell. It consists of consumptive use and exported water.

The ground-water system in the upper Pickering Creek basin (1977) is virtually unstressed. Scattered homes, farms, and two small residential developments obtain their water from domestic wells. Most of the water pumped, however, is returned to the local ground-water system through septic systems. Water is not exported by sewers or by any other means. Consequently, all calibration runs assume zero pumpage. The pumpage parameter is used in the predictive runs to simulate increased consumptive use and exportation of water. (See section on utilization.) 
A steady-state simulation was used to calibrate transmissivity and to set up wails initial conditions for a transient test of the model. (See section on

transmissivity for discussion of calibration.) The middle of a 2-month period of general recession of ground-water levels and base flows (August 20, 1975) was chosen as the beginning of the transient test. The recharge rate for the steadystate run, $4.68 \times 10^{-8} \mathrm{ft} / \mathrm{s}$, is the sum of the base $\mathrm{flow}(6.6 \mathrm{ft} / \mathrm{s})$ at the Pickering Creek gage on August 20, 1975, and the estimated ground-water ET. (See step 5 of the model development.)

Distribution of base flow over the basin for the steady-state simulation is shown in figure 10. Low-flow (base-flow) measurements were made September 26 and 27, 1967, at several locations in the basin by Miller, Troxe11, and Leopold (1971). Figure 11 is a plot of the 1967 measurements against the steady-state results for approximately the same locations. The model results are generally consistent with all of the measurements except the one associated with cell 13,29. Figure 15 of Miller, Troxell and Leopold (1971, p. A25) indicates that this measurement may be anomalous and may not represent base flow.

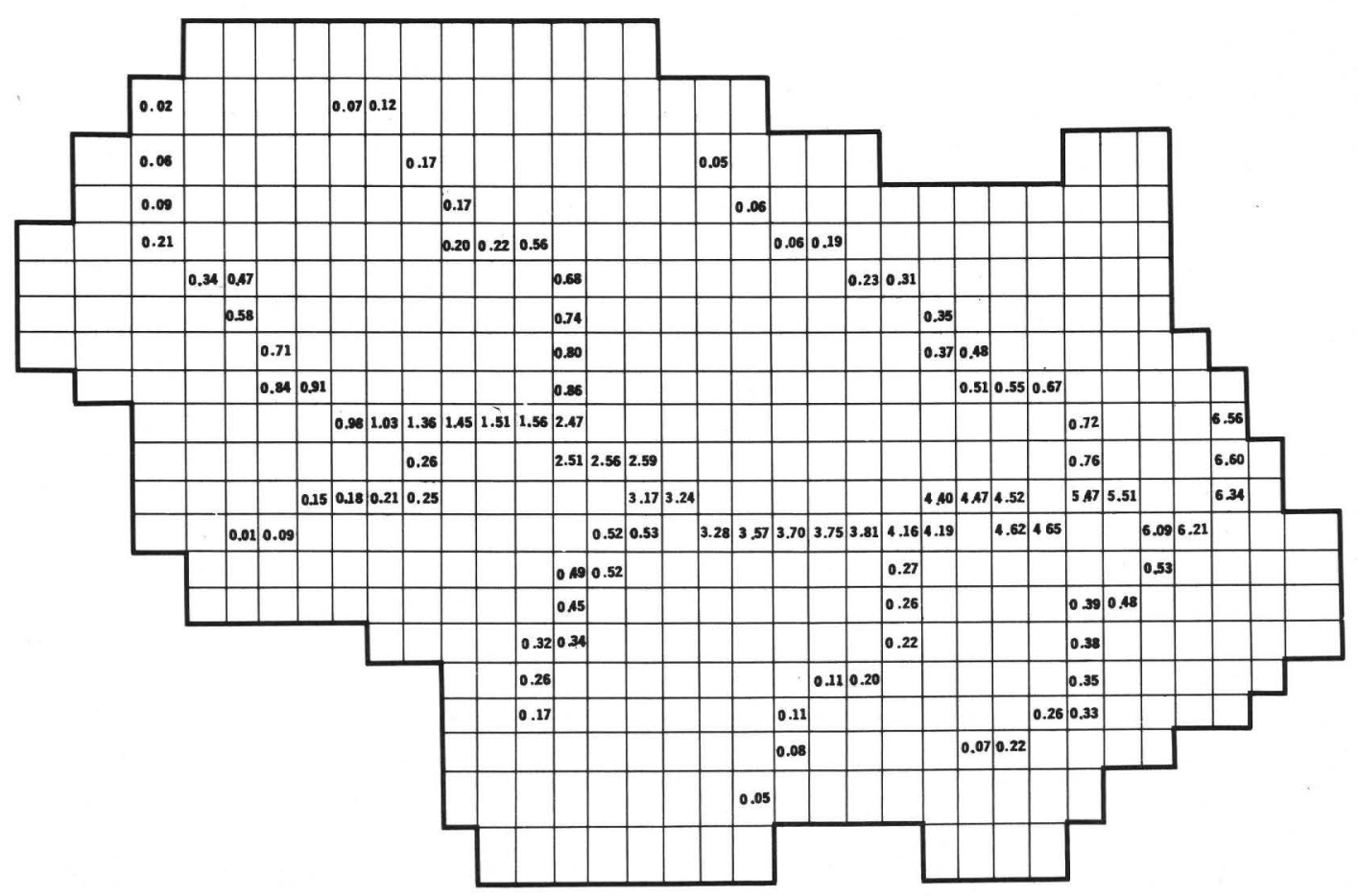

MODEL BOUNDARY

1.51 STREAM CELL-- Number is cumulative base flow in cubic feet per second. 


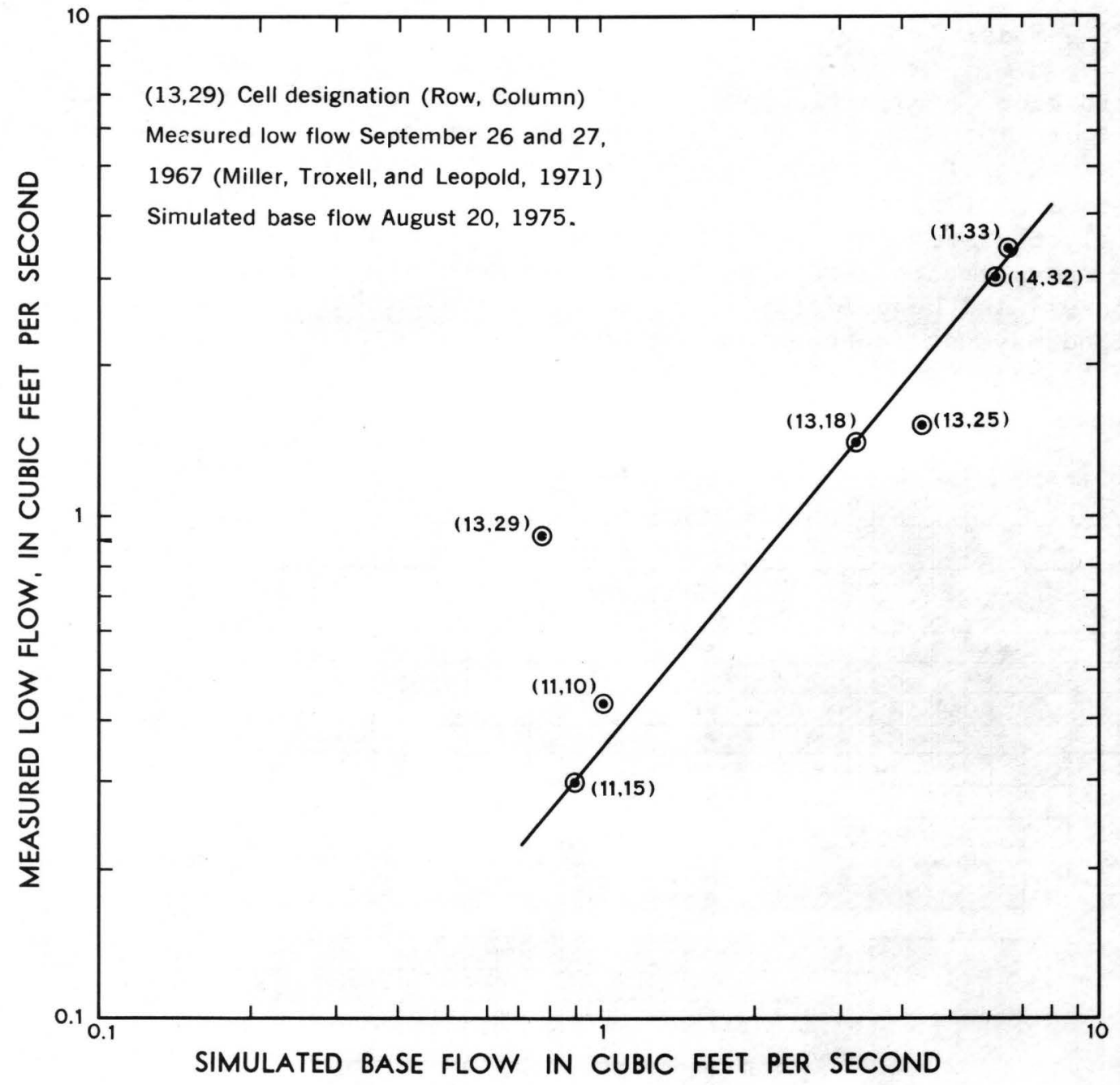

FIGURE 11..- RELATION OF LOW FLOW MEASUREMENTS TO SIMULATED BASE FLOW. 


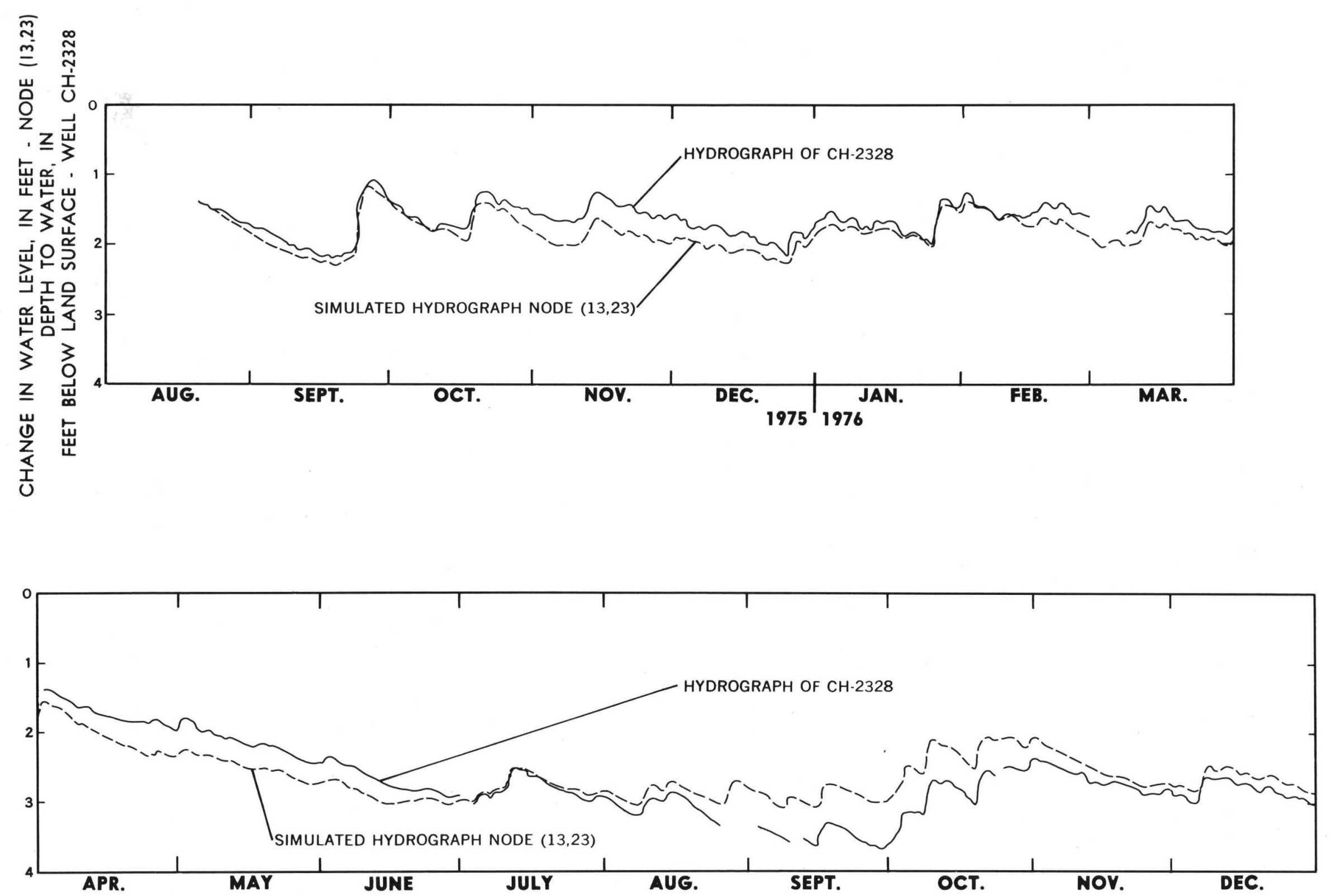

FIGURE 12. -- SIMULATED WATER-LEVEL HYDROGRAPH COMPARED TO OBSERVED HYDROGRAPH OF WELL CH-2328. 
The transient test, step 6 of the model development, covered the period from August 20, 1975, to December 31, 1976. Figure 9 compares a hydrograph of base flow from this transient test with hydrographs of streamflow at the Pickering Creek gaging station and estimated base flow. Although the comparison is adequate, better information on ground-water ET is needed to improve the simulated base flow.

Figure 12 compares daily water levels from an observation well with the simulated water levels of cell 13,23 from the transient test. Although the observation well ( $\mathrm{CH}-2328$ ) is 3.6 miles north of the modeled basin, precipitation is assumed to be very nearly the same at the well as in the basin. Hydrologic and geologic conditions are much the same, and the geologic unit at the well also underlies most of the modeled basin. The magnitude and frequency of water-level changes in a well in a similar hydrologic setting within the basin should be comparable to changes in the observation well. Cel1 13,23 represents a similar hydrologic setting in the model, and the figure shows that the magnitude and frequency are similar.

Daily water levels were not available from wells within the basin, but one well has been measured monthly for several years. The location of this we11 ( $\mathrm{CH}-1229)$ corresponds to cell 16,6 in the model. In figure 13, simulated water levels for cell 16,6 from the transient test are compared to measured water levels in well $\mathrm{CH}-1229$. The head values shown for cell 16,6 were picked for the same day or for the day nearest to the day $\mathrm{CH}-1229$ was measured.

Tests of the model showed good correlation with base flow and water-level fluctuations, and the distribution of the base flows within the model area were consistent with measurements. These tests also indicated that certain types of additional information would be useful, particularly more water-level and evapotranspiration data and synoptic base-flow measurements in the subbasins.

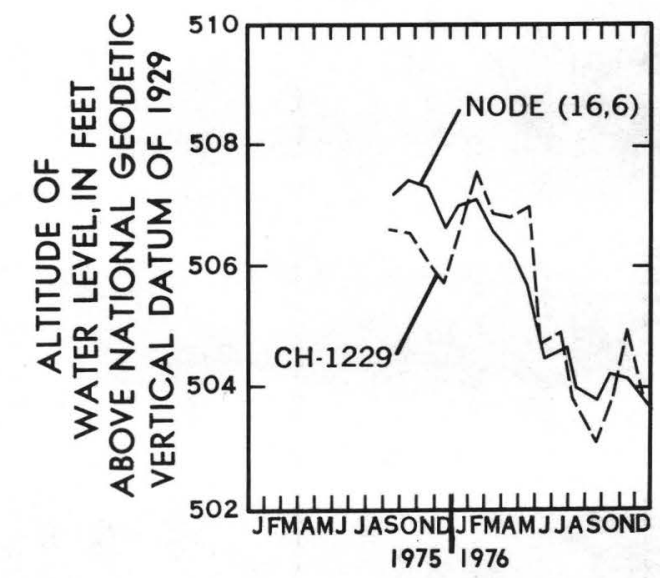

FIGURE 13.-- SIMULATED WATER LEVEL AT NODE

$(16,6)$ COMPARED TO OBSERVED WATER LEVEL

IN WELL CH-1229. 
The basin model incorporates many assumptions and generalizations; consequently, it represents an idealized basin that is similar to, but not necessarily the same as, the upper Pickering Creek basin. In the following sections of the report, predictive simulations examine the relative effects of various development schemes on this idealized basin. It is unlikely that development in the upper Pickering Creek basin will follow a pattern identical to any of the schemes. Even if one were followed, the real basin would not react precisely as the model, although the reaction would be similar. The predictive simulations were designed to show the general magnitude of the effect of a particular development scheme and to provide a comparison of the relative effects of different schemes.

Tests comparing the model with the actual basin showed that the model gave reasonable results for assumed steady-state conditions and for transient conditions where water levels remain in the normal zone of fluctuation. In some of the predictive simulations, water levels fell below the normal zone of water-level fluctuation (drawdown more than about 15 feet below the long-term average level) in a few cells. In general, hydrologic characteristics in the basin become less favorable with depth, but the model assumes no change. Consequently, drawdown indicated by the model for such cells may be less than the actual values would be.

\section{Initial Conditions}

In order to stress the hydrologic system over a period of time, a set of initial conditions approximating long-term average conditions in the basin were developed by modifying the steady-state run used for calibration. The recharge rate was changed to a long-term average rate of $3.78 \times 10^{-8} \mathrm{ft} / \mathrm{s}$. This rate was calculated by adding the long-term average base flow, $5.2 \mathrm{ft} / \mathrm{s}$, and estimated average ground-water ET. The modified steady-state run generated a set of heads that represent long-term average conditions in the basin if it were to remain undeveloped. This set was used as the initial head in al1 simulations stressing the hydrologic system. The heads resulting from stress $=50$ simulations are compared to these initial values to determine the relative effect compArisall of stresses on the system. The modified steady-state run generated a base flow of $5.23 \mathrm{ft}^{3} / \mathrm{s}$, which represents the long-term average base flow if the basin were to remain undeveloped. Base flows generated by stress simulations are compared to this figure to determine the effect of the stress upon the base flow.

\section{Prediction Simulations}

Different combinations of conditions were simulated in order to compare the potential effects of various stresses on the hydrologic system. An area of $1 \mathrm{mi}^{2}$ was chosen for simulation of development in the basin ( $\mathrm{fig} .14$ ). The area of development is designed to simulate residential development only. However, some simulations may be analogous to other types of development if pumping and recharge conditions are the same. The initial conditions are those of the undeveloped basin. The instant the simulation begins, a11 stress conditions immediately take place. 


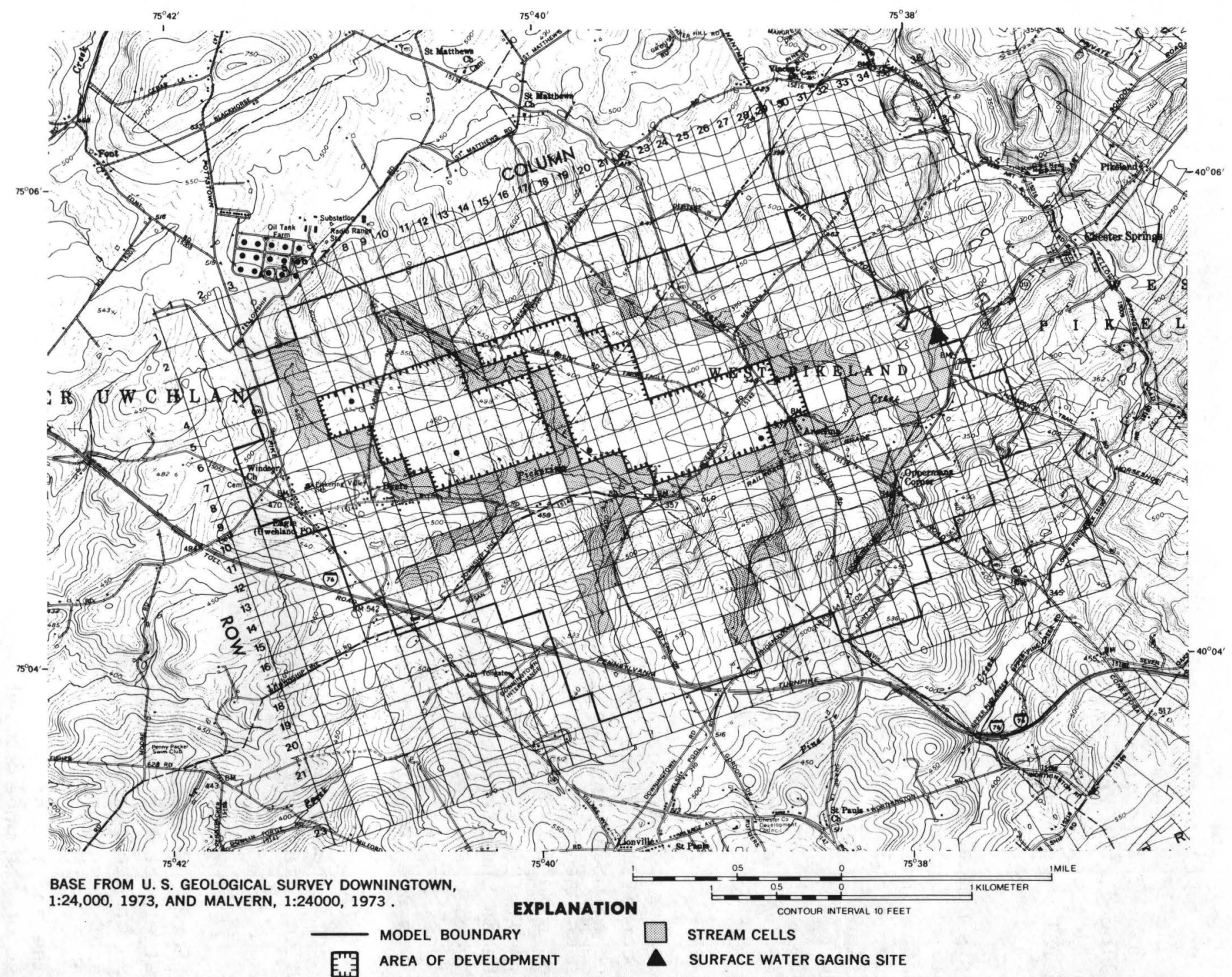

- location of pUblic SUPPLy Wells

FIGURE 14... SIMULATED AREA OF DEVELOPMENT. 
Stress simulations utilize combinations of the following conditions. The area of development is divided into 1-acre, 1/2-acre, or 1/4-acre lots. No provisions for open space were made. Wastewater disposal is by individual onsite septic systems or by public sewers in which the wastewater is assumed to be removed from the basin. It is also assumed that no leakage from or into the sewer system takes place. The source of water supply is either individual domestic wells or five public-supply wells located in areas favorable for such wells. No reduction in recharge is assumed for most simulations. In some simulations recharge is arbitrarily reduced 1 or 5 percent over the area of development.

A11 stress simulations were made for a period of 20 years. Changes in water level and base flow were examined after 1,2,3, 4, 5, 10, 15, and 20 years of pumping. Maps of water-level decline are based on the average decline in a cell; drawdown near a pumping well would be much greater. Graphs show change in base flow at the stream cell that corresponds to the location of the surface-water gage.

Water use in the area of development was estimated by using the average of 3.3 persons per housing unit estimated by the Chester County Planning Commission (1973) and a rate of 72 gallons per person per day, which is the average rate of water use for public water companies supplying strictly residential developments in Chester County in 1974. In simulations where the area is not sewered, the pumping rate is equal to an estimated consumptive use of 10 percent of the wateruse rate. The other 90 percent of the water is assumed to be recharged to the hydrologic system through septic systems. In simulations where the area is sewered, the pumping rate is equal to the water-use rate.

Water-use rates for simulations with domestic we11s, based on a 1/2-acre lot size, were calculated to be $3,041 \mathrm{gal} / \mathrm{d}$ per cell. This is equal to a continuous pumping rate of $4.8 \times 10^{-3} \mathrm{ft}^{3} / \mathrm{s}$. Public-supply wells each serve areas ranging in size from 115.2 to 140.8 acres. The pumping rate for each well was calculated to be from 54,743 to $66,908 \mathrm{gal} / \mathrm{d}$ per well. This is equal to a continuous pumping rate of $8.7 \times 10^{-2}$ to $1.06 \times 10^{-1} \mathrm{ft}^{3} / \mathrm{s}$ per well. Simulations using a 1/4-acre lot size use pumping rates twice as large.

In all simulations, except that of sewering, the undeveloped basin, the effect of sewering is applied only to the area of development. Sewering the rest of the basin is neglected, so that only the changes in the hydrologic system caused by the area of development may be seen.

\section{Changes in the Hydrologic System with Time}

Figure $15 \mathrm{~A}-\mathrm{I}$ illustrates the change in the hydrologic system with time. The area of development is divided into 1/2-acre lots with public sewers and domestic wells. The water-level decline from pumping is shown after $1,2,3,4$, 5, 10, 15, and 20 years. The area of water-level decline spreads out during the first 3 years. After the fourth year of pumping, the area is near its maximum extent. Future water-level declines come mainly from within this area as the cones of depression deepen and spread out. There is little change in the hydrologic system after the 15th year of pumping, indicating that the system is approaching equilibrium. Most simulations presented in this report generally follow this pattern. 


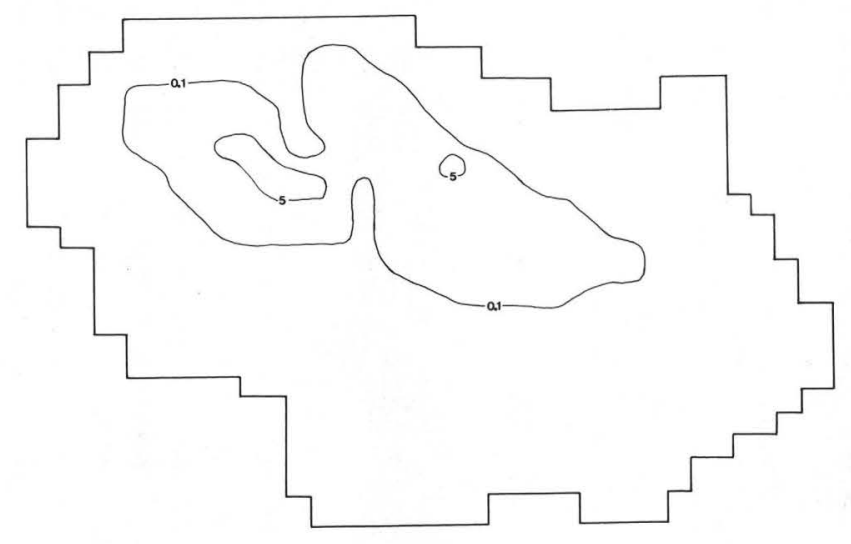

15A. - Simulated decline in water level after 1 year of pumping.

๗

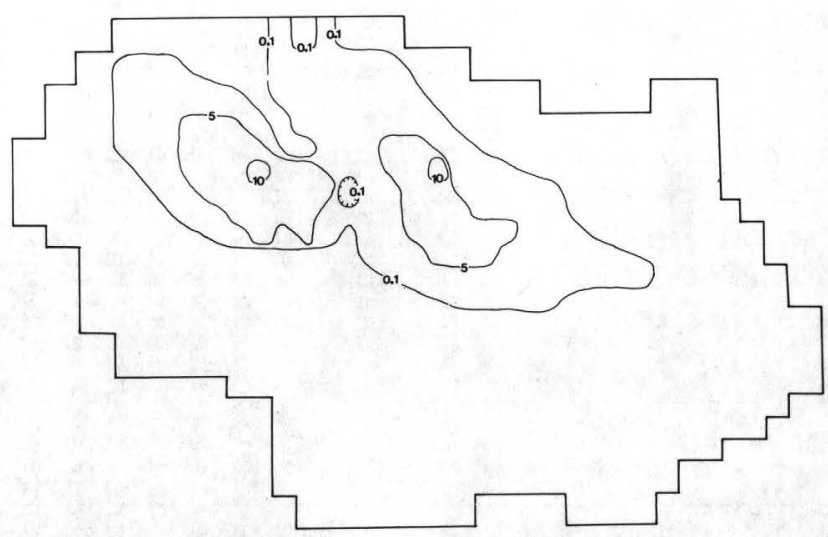

15C.-- Simulated decline in water level after 3 years of pumping.

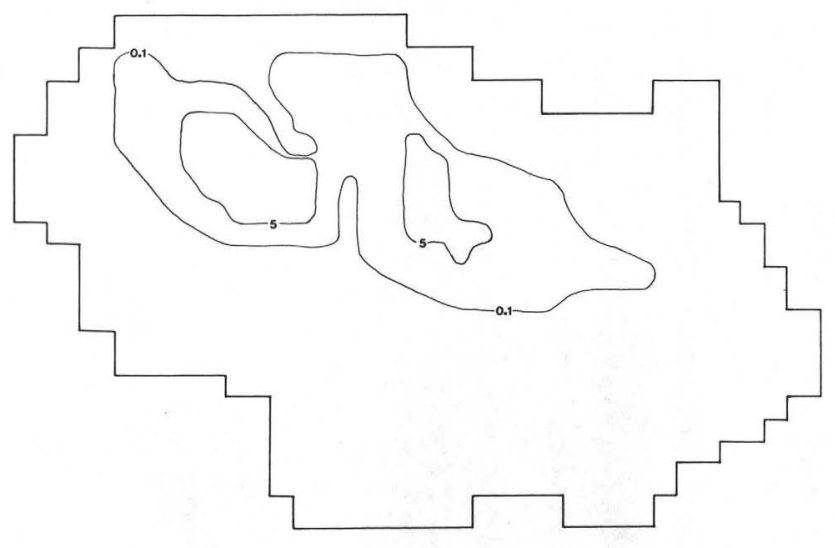

15B.-- Simulated decline in water level after 2 years of pumping.

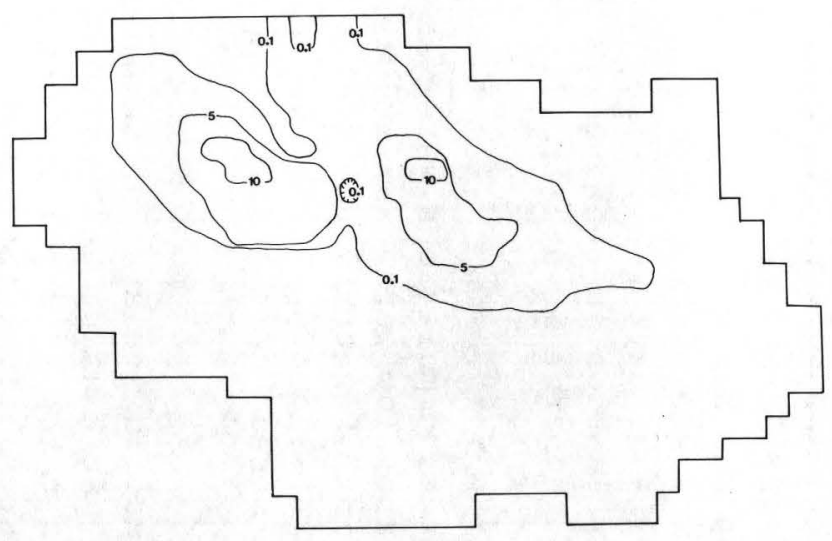

15D.-- Simulated decline in water level after 4 years of pumping. 


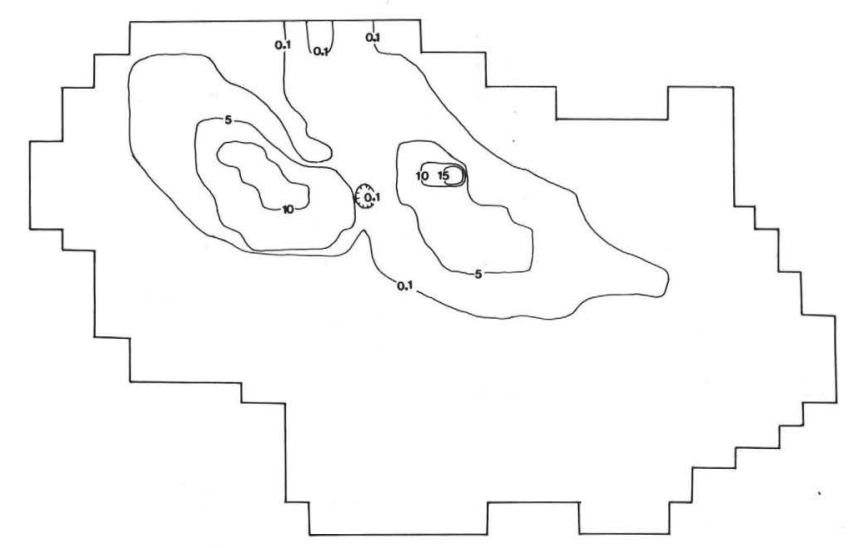

15E. -- Simulated decline in water level after 5 years of pumping.

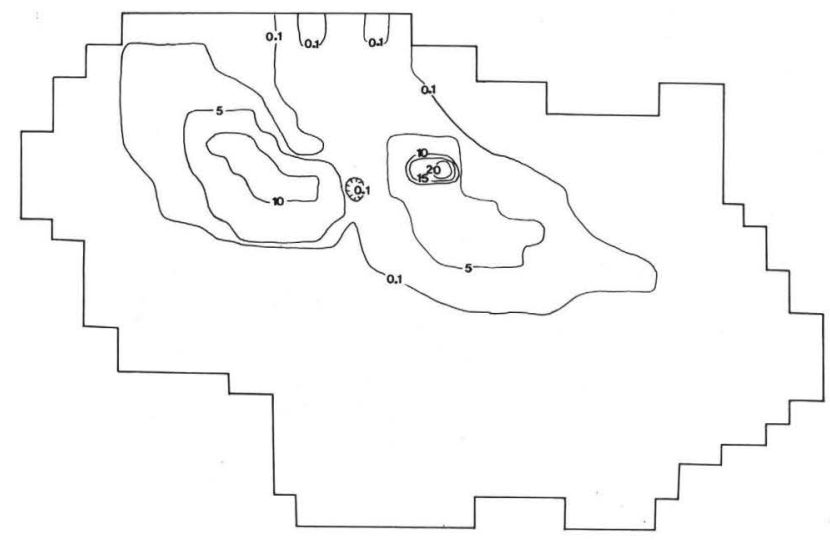

15G.-- Simulated decline in water level after 15 years of pumping.

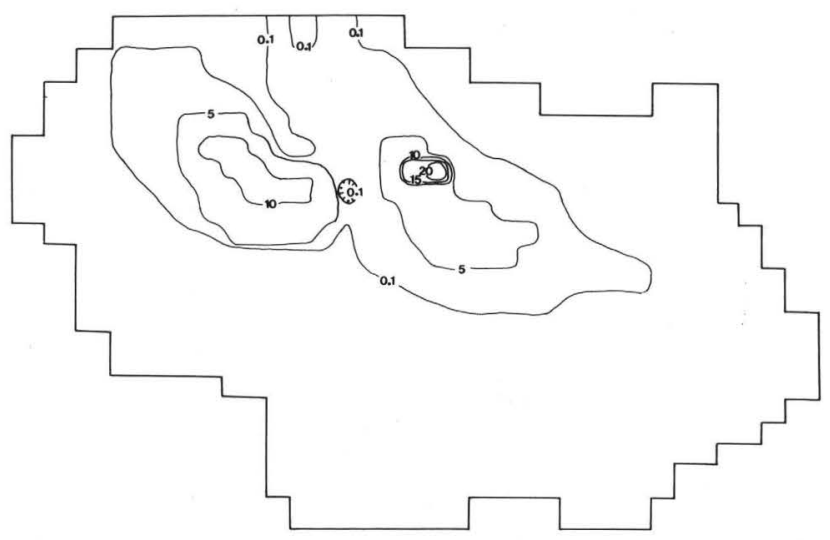

15F.-- Simulated decline in water level after 10 years of pumping.

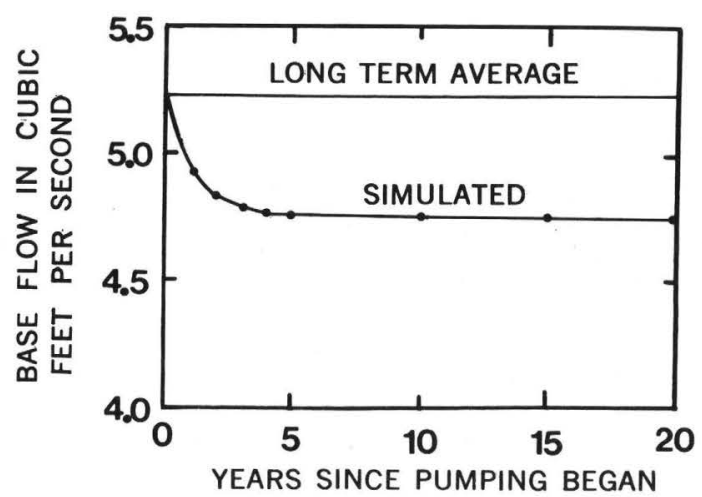

FIGURE 15. -- SIMULATED DECLINE IN WATER LEVEL AND REDUCTION IN AVERAGE BASE FLOW WITH TIME. AREA OF DEVELOPMENT IS DIVIDED INTO $1 / 2$-ACRE LOTS WITH DOMESTIC WELLS AND SEWERS.

\section{EXPLANATION}

MODEL BOUNDARY

LINE OF EQUAL WATER LEVEL DECLINE--

intervals 0.1 and 5 feet. 


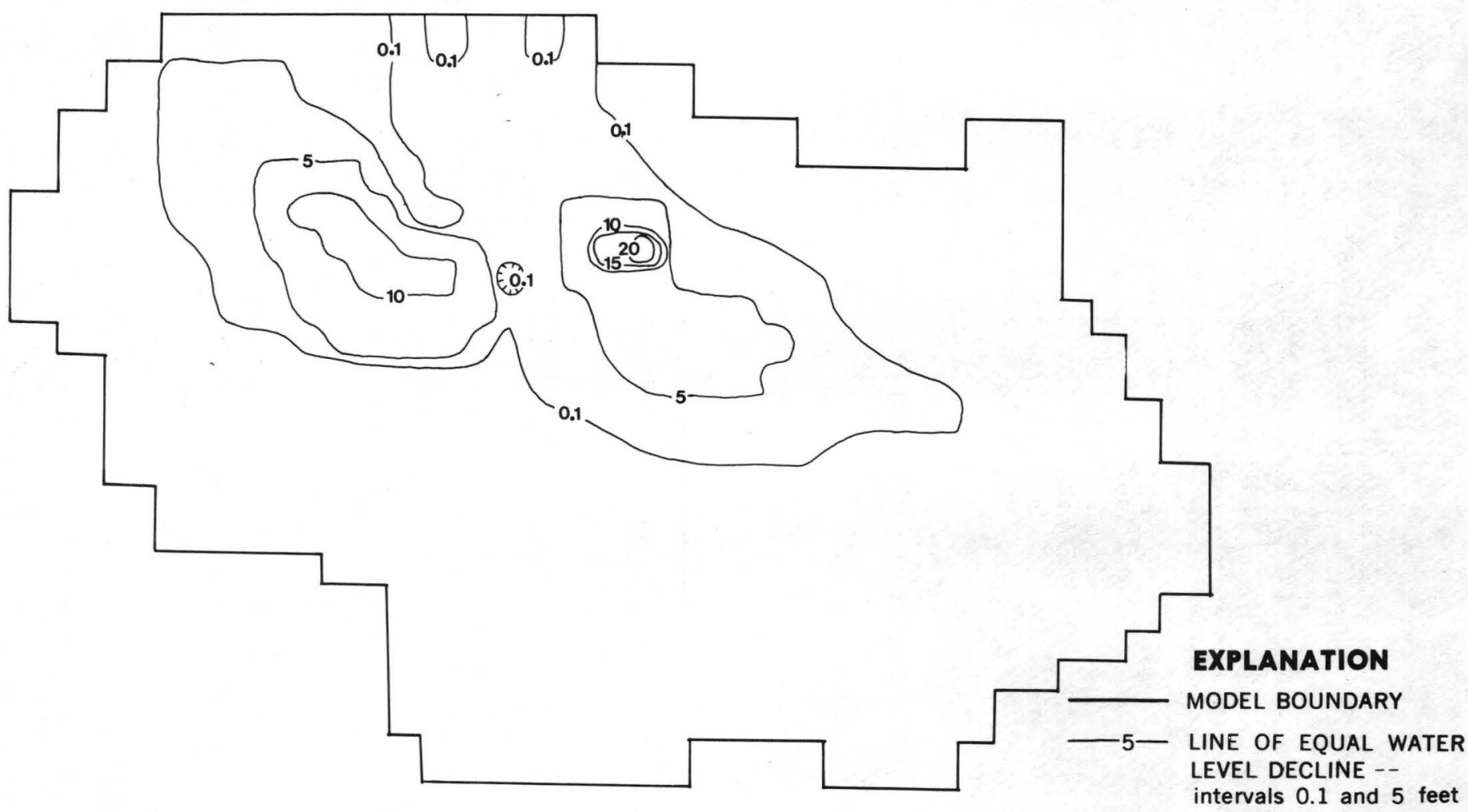

15H. -. Simulated decline in water level after 20 years of pumping.

FIGURE 15. -- CONT'D.

The reduction in average base flow of Pickering Creek is shown in figure 15I. Most of the base-flow reduction takes place in the first 5 years. During the first 5 years, the reduction is 8.5 percent and during the next 15 years it is only an additional 0.1 percent.

\section{Sewering the Undeveloped Basin}

A simulation was made to determine the effects of sewering the basin if it were to remain undeveloped. Estimates of water use based on the number of houses and other buildings in each cell were determined from topographic maps. Figure 16 shows the simulated decline in water level after 20 years. The largest water-level decline in a cell was 3.6 feet. Average base flow was reduced 2 percent. The hydrologic system was near equilibrium after 4 years, and no change occurred after the 15 th year, indicating it had reached equilibrium by then. 


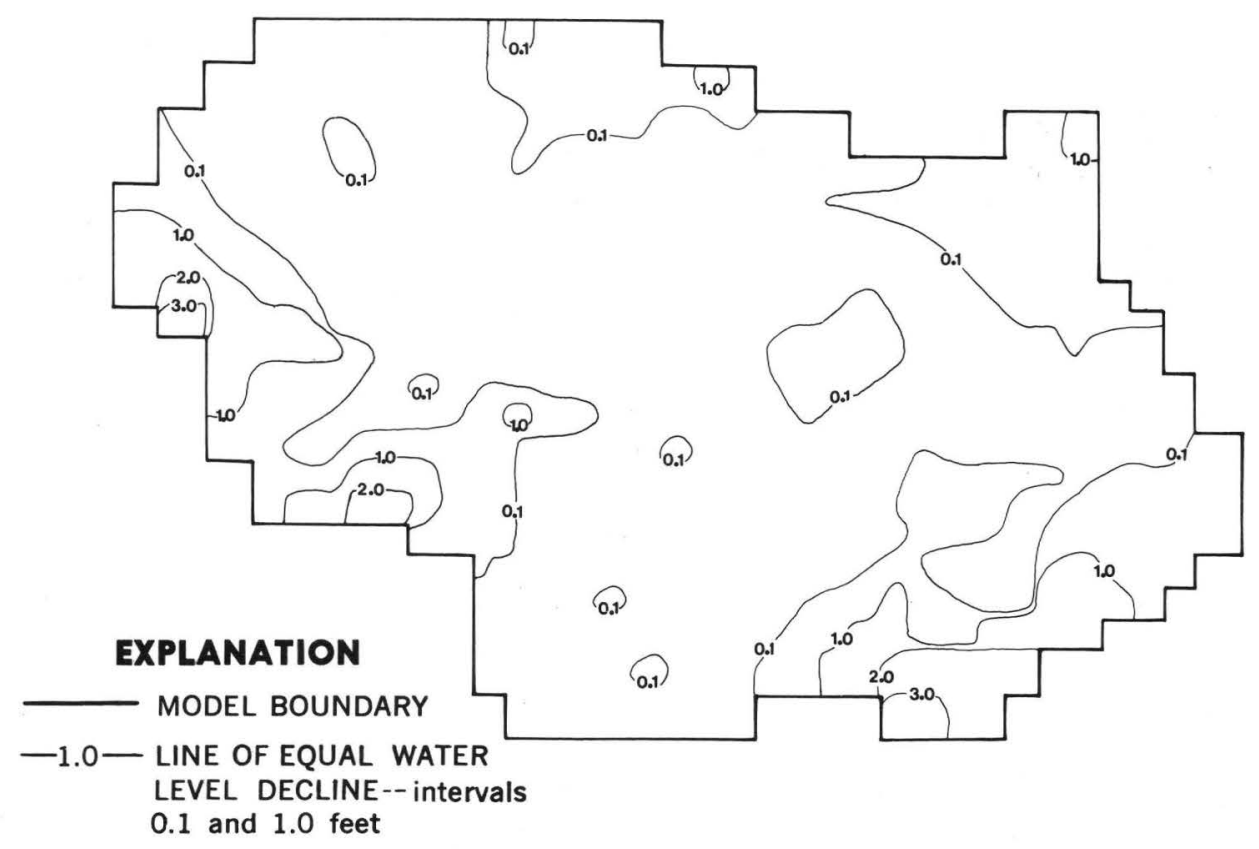

\section{FIGURE 16. -- SIMULATED DECLINE IN WATER LEVEL 20 YEARS AFTER SEWERING THE UNDEVELOPED BASIN.}

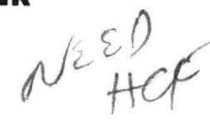

Water-level declines extend to the boundary of the model and would probably shift the ground-water divide, so that It would no longer coincide with the topographic or surface-water divide. This would induce the inflow of ground water from adjacent basins. To estimate the quantity, the simulation was repeated with constant-head boundaries inserted where the decline extends to the model boundary. The constant-head simulation showed an inflow of $0.04 \mathrm{ft}^{3} / \mathrm{s}$ of ground water from the adjoining basins.

\section{Sewering the Area of Development}

Simulations were made to examine the effects of sewering the area of development. Figure 17 shows the simulated water-level decline after 20 years of pumping where the area of development is divided into 1/2-acre lots that have domestic wells and septic systems. The greatest water-level decline in a cell was 0.9 feet. Average base flow was reduced less than 1 percent. 


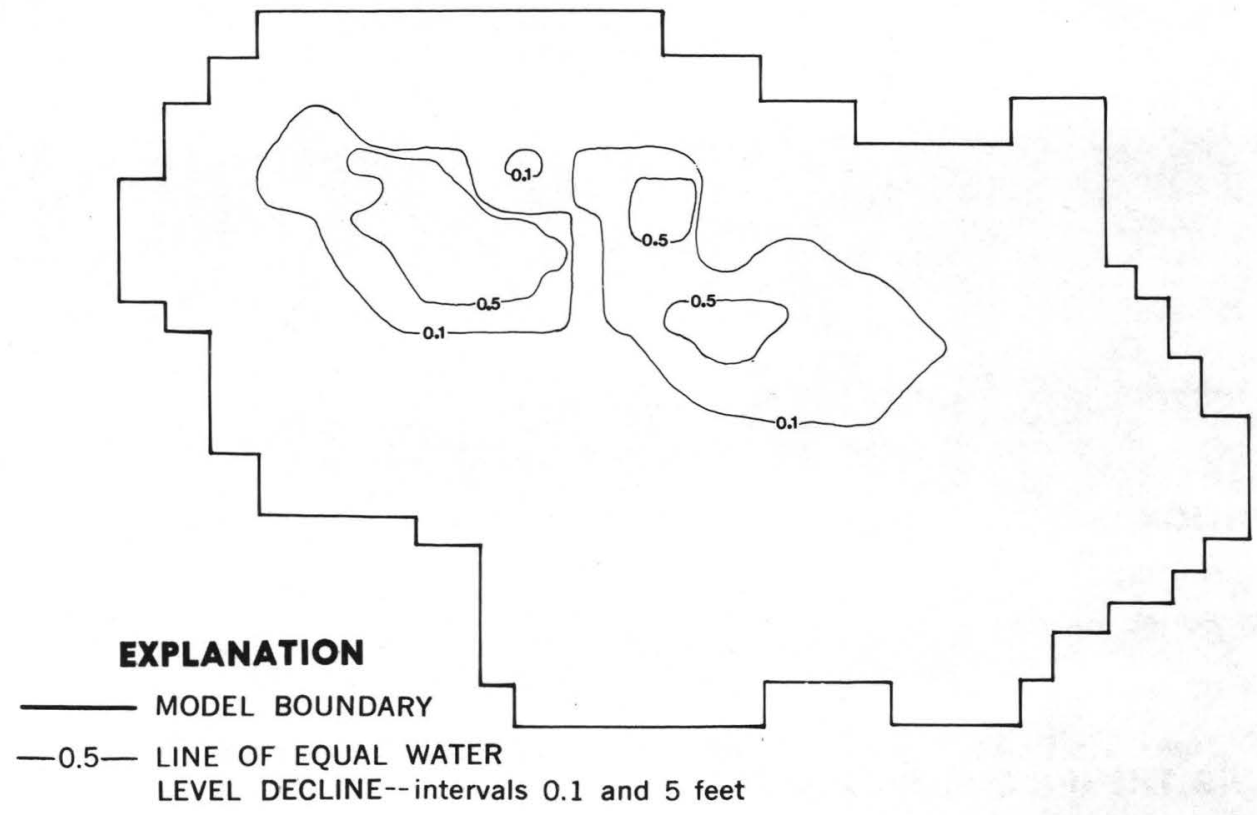

FIGURE 17. -- SIMULATED DECLINE IN WATER LEVEL AFTER 20

YEARS OF PUMPING. AREA OF DEVELOPMENT IS DIVIDED INTO $1 / 2$-ACRE LOTS WITH DOMESTIC WELLS AND SEPTIC SYSTEMS.

Figure $15 \mathrm{H}$ shows the same set of conditions except the septic systems have been replaced by public sewers. In this simulation, the area affected by water-level decline is much larger than in figure 17, and the declines are much greater. However, even though the greatest water-level decline in a cell was 23.2 feet, only 9 cells showed declines greater than 10 feet. Reduction of base flow, shown in figure 15I, is 8.6 percent.

In figure $15 \mathrm{H}$ water-1evel declines extend to the boundary of the model, but are only 0.1-0.2 foot in cells along the boundary. This simulation was repeated using a constant-head boundary where the water-level decline reaches the model boundary, to determine the quantity of induced interbasin flow. The constanthead simulation showed an induced flow of less than $0.01 \mathrm{ft} / \mathrm{s}$. A constant-head boundary was also inserted in all other simulations where the water-level decline reached the model boundary. In simulations where the decline in cells along the boundary was only a few tenths of a foot, the induced interbasin flow was less than $0.01 \mathrm{ft}^{3} / \mathrm{s}$. 
Simulations were made using domestic wells or five optimally located publicsupply wells in otherwise identical situations to determine the difference in effect upon the hydrologic system. Both methods of supply produced a reduction in average base flow of 8.6 percent, as each removed the same amount of water from the system. Figure 18 shows the simulated water-level decline if a public-water supply replaced the domestic wells. (Compare with fig. 15H.) Cones of depression have formed around three of the public-supply wells. The greatest water-1evel decline in a cell was 19.5 feet.

Leakage rates to stream cells bordering the area of development were analyzed to determine whether water pumped from the public supply wells came mainly from diverted base flow or from induced infiltration of stream flow. Leakage rates, after development, were less than before development in most of the stream cells, which indicates that the water came from diversion of base flow. None of the stream cells showed a negative leakage rate, which would have been indicative of induced stream flow. The cones of depression that formed around the two publicsupply wells near the stream were much shallower than the cones formed around the wells farther from the stream. The reduction in the leakage rate in the stream cells near these two wells is greater than the reduction in the leakage rate near the other three wells. The wells closer to the stream derive more water from diverted base flow and less from storage than wells located farther from the stream.

Public-supply wells are located in cells having relatively high transmissivities and the potential for developing relatively large water supplies. Domestic wells are in all cells in the area of development and all have the same pumping rate.

Lot Size

To examine the effect of residential development of different lot sizes, the pumping rate was varied, so this section may also be viewed as examining the effects of changing the pumping rate. The pumping rate is a function of lot size because as lot size decreases, the population per acre increases and home water use increases. All simulations discussed in this section are for lots with public water and sewers. (Pumping rates are discussed in the section "Prediction Simulations.")

Figure 19 shows the result of developing 1-acre lots. After 20 years of pumping, small cones of depression have formed around three of the pumping wells. The area of decline touches the boundary at only one cell, which has a waterlevel decline of 0.1 foot. The greatest water-level decline in a cell is $9.1 \mathrm{feet}$. Average base flow is reduced 4.2 percent.

For figure 18, the lot size is decreased to half an acre by doubling the pumping rate. The cones of depression around three of the pumping wells have deepened and spread. The greatest water-level decline in a cell is $19.5 \mathrm{feet}$. The area of decline has spread farther and now touches the boundary at several cells. Average base flow is reduced 8.6 percent. 


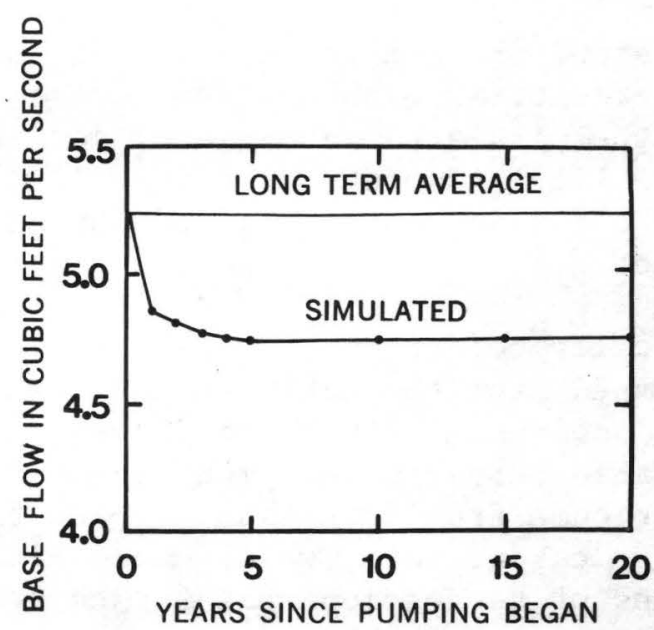

Simulated reduction in average base flow.

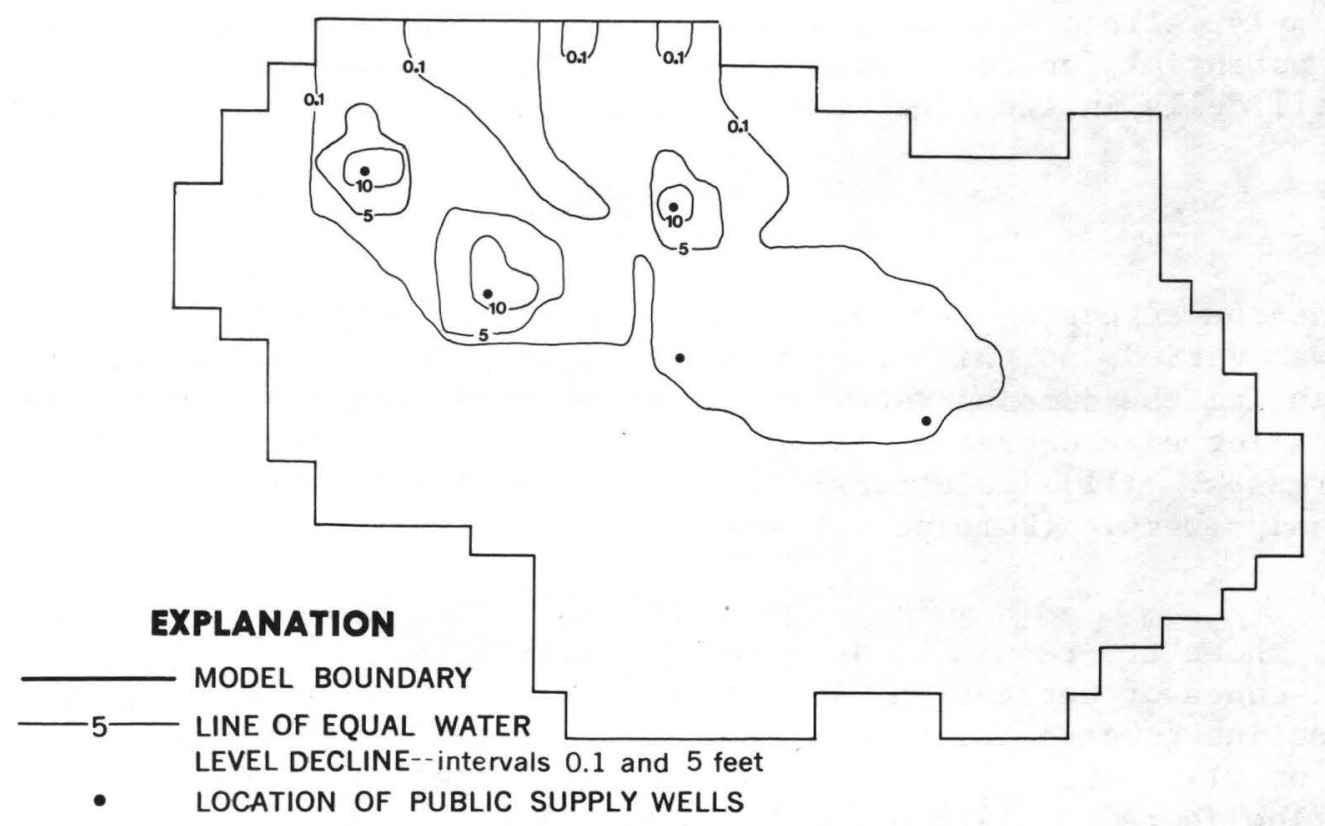

FIGURE 18. -- SIMULATED DECLINE IN WATER LEVEL AND REDUCTION IN AVERAGE BASE FLOW AFTER 20 YEARS OF PUMPING. AREA OF DEVELOPMENT IS DIVIDED INTO $1 / 2$-ACRE LOTS WITH PUBLIC WATER AND SEWERS. 

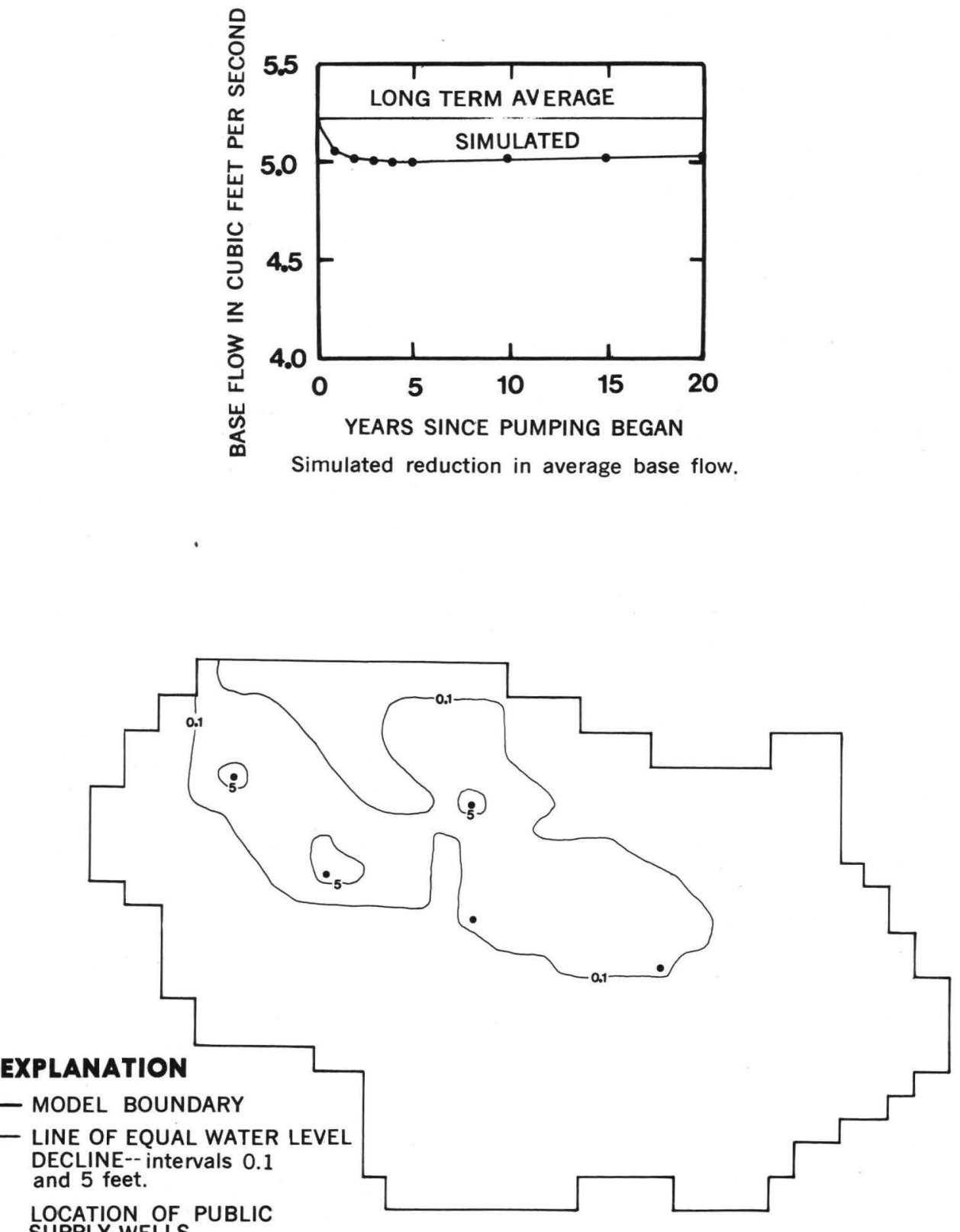

FIGURE 19. -. SIMULATED DECLINE IN WATER LEVEL AND REDUCTION IN AVERAGE BASE FLOW AFTER 20 YEARS OF PUMPING. AREA OF DEVELOPMENT IS DIVIDED INTO I ACRE LOTS WITH PUBLIC WATER AND SEWERS. 
The lot size for figure 20 is decreased to a quarter of an acre as the pumping rate is again doubled. The area of water-level decline has grown and the cones of depression around the pumping wells have deepended and spread. The greatest waterlevel decline, $47.8 \mathrm{feet}$, occurs at a cell in one of these cones. Note that the contour interval on this map had to be increased. Average base flow is reduced 17.4 percent.

\section{Reduction in Recharge}

Because many studies (Sawyer, 1963, for example) have shown that urbanization causes a reduction in recharge, simulations were made in which recharge was reduced by 1 and 5 percent over the area of development. The simulations discussed in this section are of 1/2-acre lots that have public water and sewers. These conditions with no reduction in recharge are shown in figure 18 .

Figure 21 shows the simulated decline in water level after 20 years of pumping with the recharge reduced 1 percent over the area of development. The area of decline is about the same as in figure 18. The greatest decline in a cell is only 0.3 foot more than with no reduction, or $19.8 \mathrm{feet}$. As recharge is reduced, the quantity of water available as base flow is decreased. Average base flow is reduced 8.8 percent, which is only 0.2 percent more than in the simulation in which recharge was not reduced.

Figure 22 shows the water-level decline after 20 years of pumping with recharge reduced 5 percent. In this simulation, the area of water-level decline has grown. The cones of depression around three of the pumping wells have noticeably expanded and deepened. The largest water-level decline in a cell is 20.6 feet and the reduction in average base flow is 9.5 percent.

\section{CONCLUSIONS}

The basin model developed in this study adequately represents an idealized basin similar to the upper Pickering Creek basin. This model simulates groundwater flow in deeply weathered crystalline rock that is typical of most of Chester County, Pennsylvania.

Model-development procedures began with the development of a simple linear model. Procedures for estimating parameters and methods of calibration and testing were first worked out with the linear model and the established procedures were then used to construct and calibrate the areal model of the basin.

The many hydrologic studies done in Chester County in past years provided data that made it possible to develop an approximate model of ground-water flow in a typical Chester County basin. Tests of the basin model showed that certain additional types of information would be needed to make the model more reliable. Particularly helpful would be more water-level and evapotranspiration data, synoptic base-flow measurements in the subbasins, and better information on the variation of hydraulic conductivity and specific yield.

Predictive simulations made by the model show the effects of changes on the hydrologic system. For areas supplied locally by wells, decreased lot size (increased discharge per unit area) and reduced recharge result in increased drawdowns and reduced base flow. When wastewater is exported by sewers, these effects are magnified. The simulations by the model show the relative severity of the effects of various development schemes. 


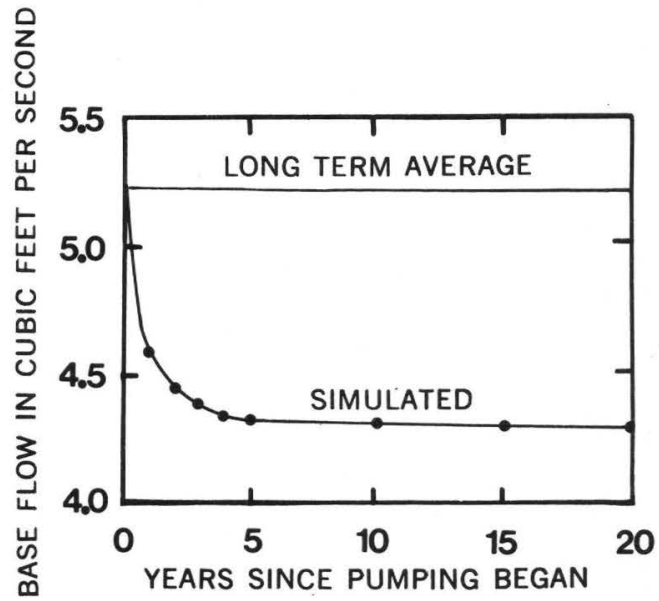

Simulated reduction in average base flow.

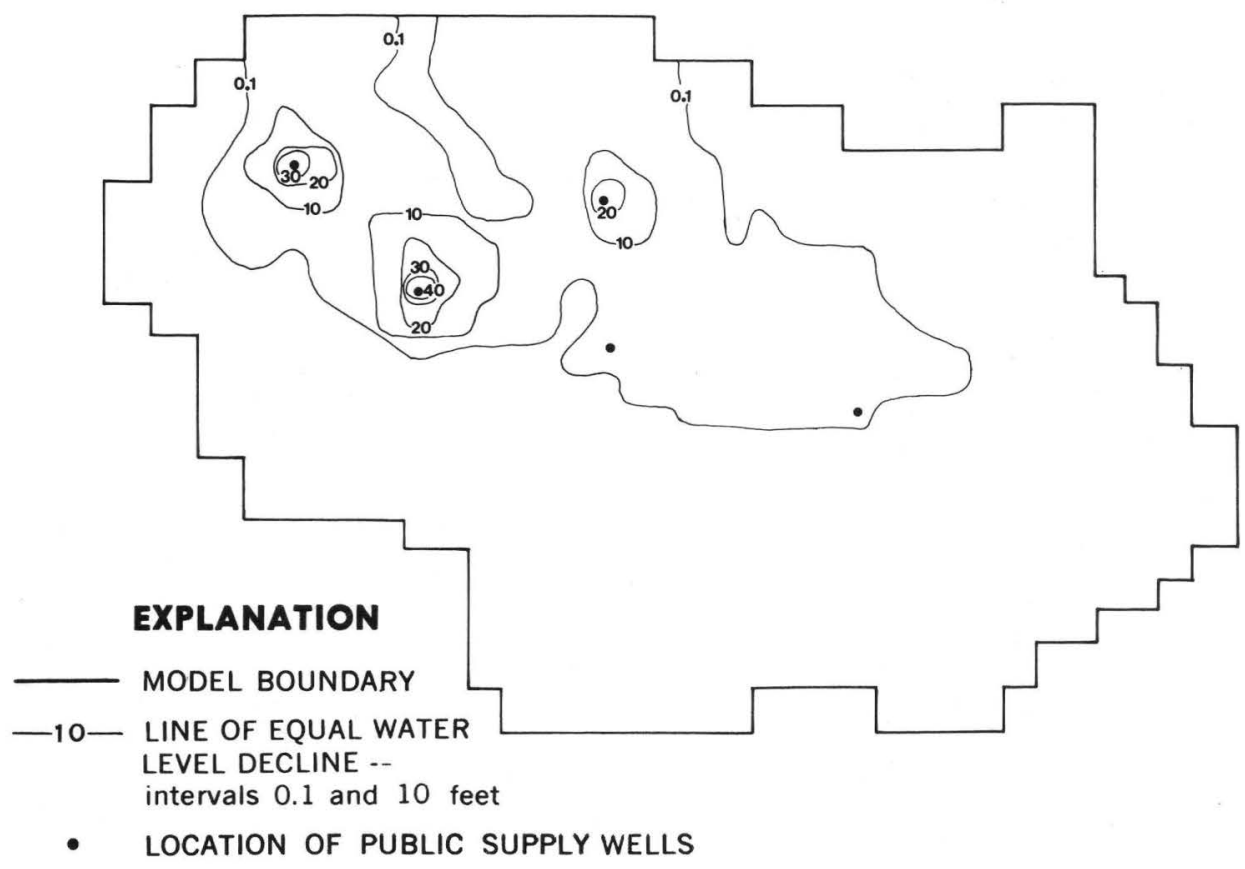

FIGURE 20. -- SIMULATED DECLINE IN WATER LEVEL AND REDUCTION IN AVERAGE BASE FLOW AFTER 20 YEARS OF PUMPING. AREA OF DEVELOPMENT IS DIVIDED INTO 1/4-ACRE LOTS WITH PUBLIC WATER AND SEWERS. 


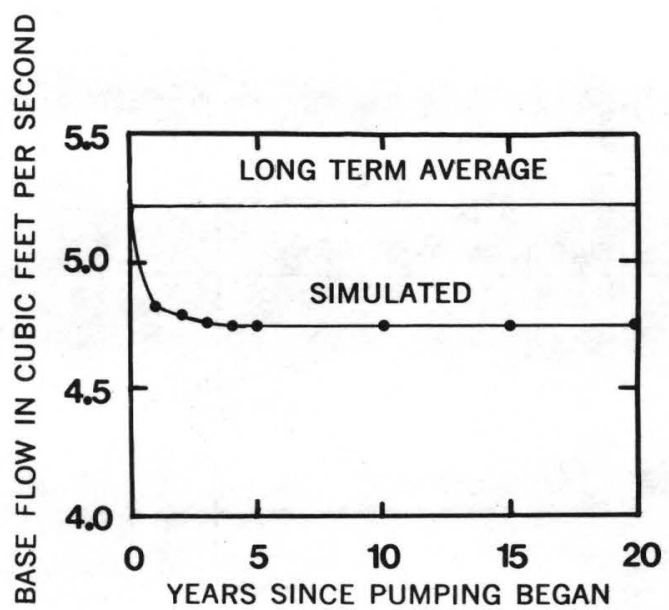

Simulated reduction in average base flow.

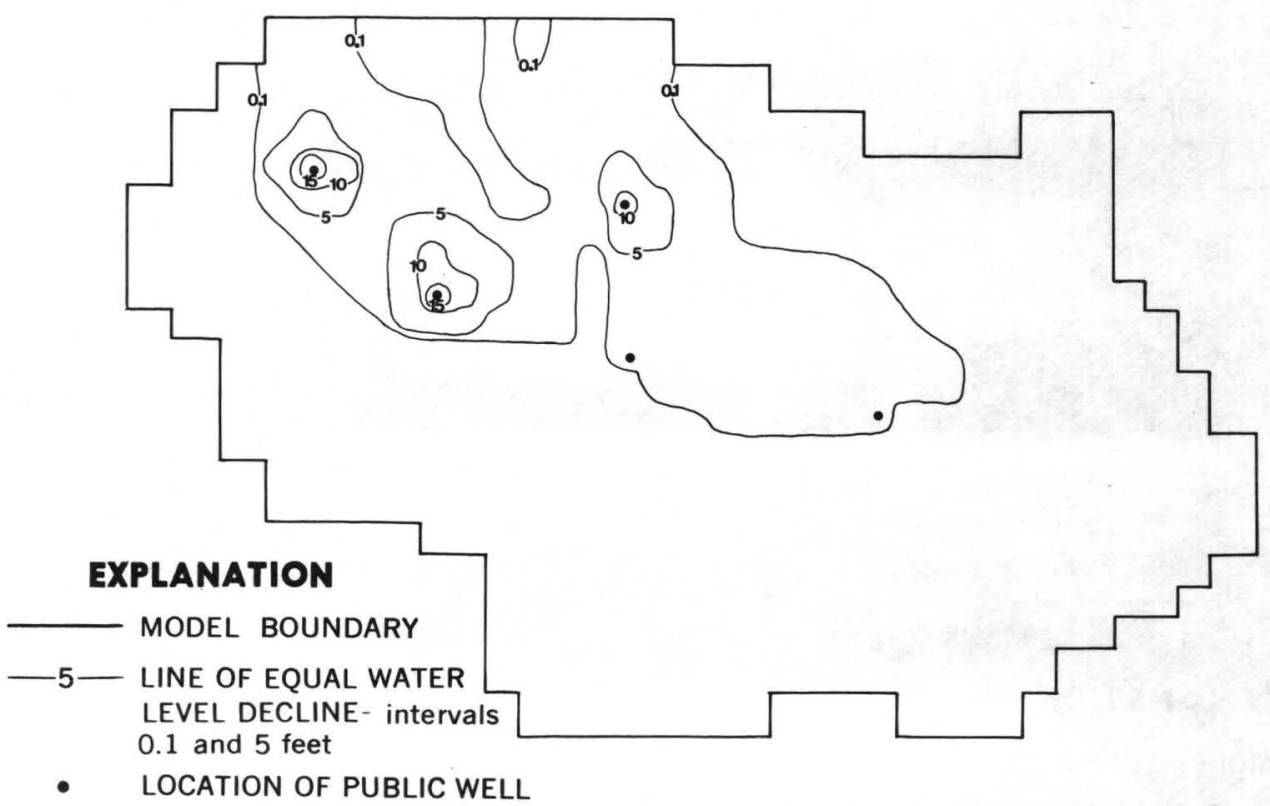

FIGURE 21. -- SIMULATED DECLINE IN WATER LEVEL AND REDUCTION IN AVERAGE BASE FLOW AFTER 20 YEARS OF PUMPING. AREA OF DEVELOPMENT IS DIVIDED INTO $1 / 2$-ACRE LOTS WITH PUBLIC WATER AND SEWERS. RECHARGE IS REDUCED 1 PERCENT OVER THE AREA OF DEVELOPMENT. 


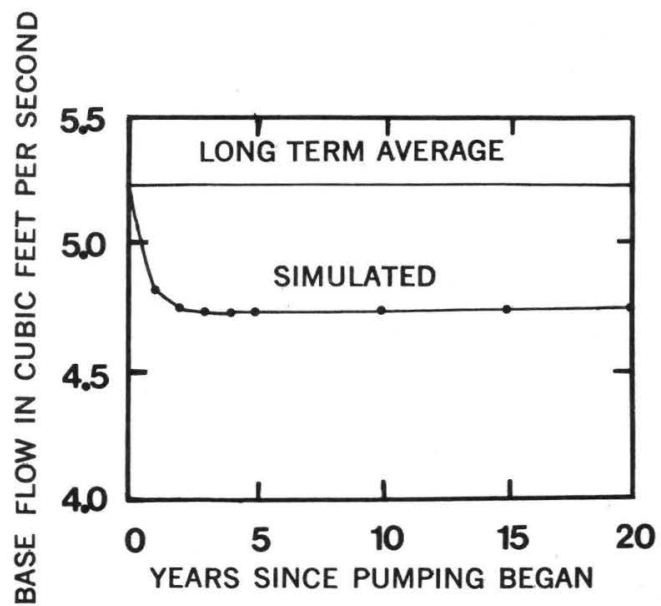

Simulated reduction in average base flow.

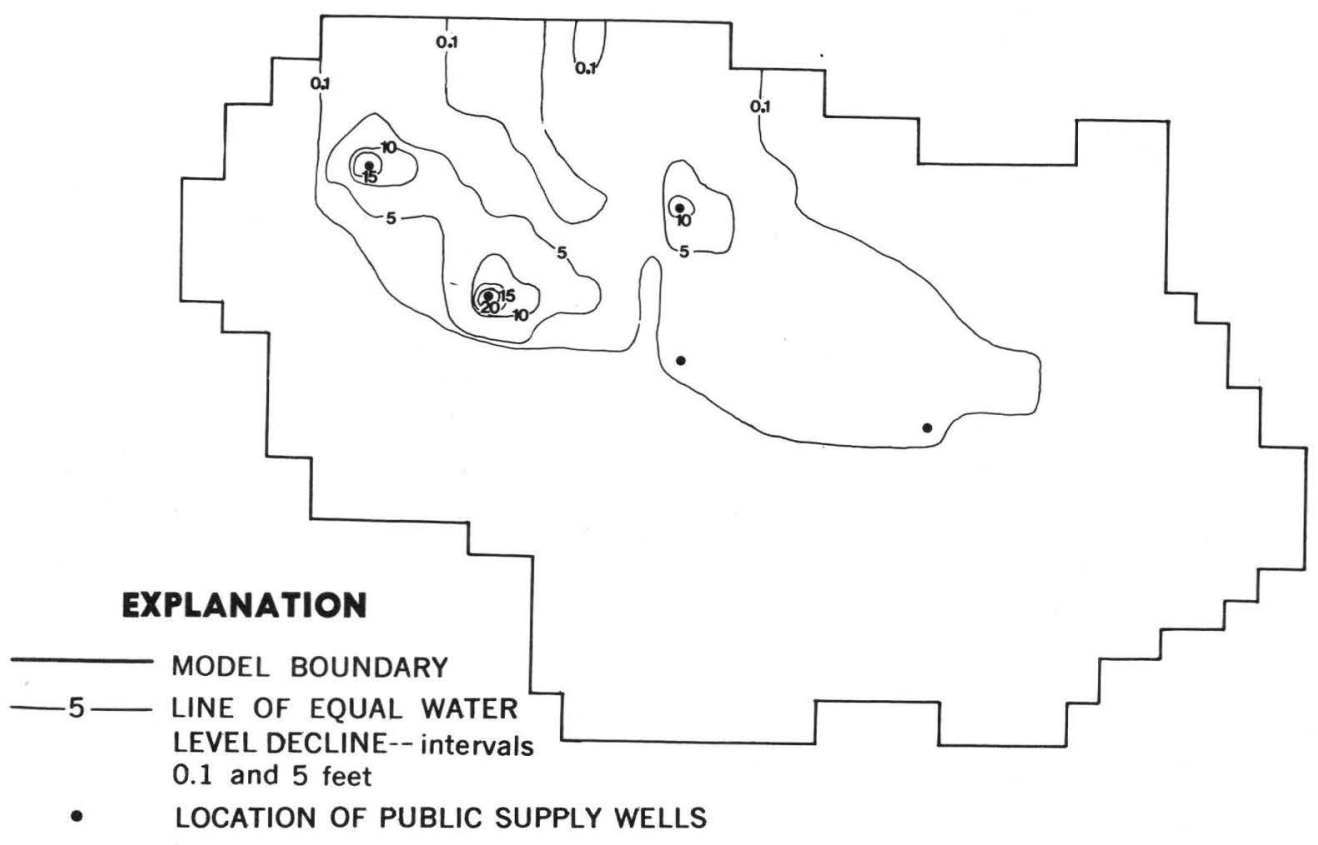

FIGURE 22.-- SIMULATED DECLINE IN WATER LEVEL AND REDUCTION IN AVERAGE BASE FLOW AFTER 20 YEARS OF PUMPING. AREA OF DEVELOPMENT IS DIVIDED INTO $1 / 2$-ACRE LOTS WITH PUBLIC WATER AND SEWERS. RECHARGE IS REDUCED 5 PERCENT OVER THE AREA OF DEVELOPMENT. 
Bascom, Florence and Stose, G.W., 1938, Geology and mineral resources of the Honeybrook and Phoenixville quadrangles, Pennsylvania: U.S. Geological Survey Bulletin 891, 145 p.

Chester County Planning Commission, 1973, Housing Analysis: West Chester, Pa.: Chester County Planning Commission, 129 p.

Kunkle, M.W., 1963, Soil Survey of Chester and Delaware Counties, Pennsylvania: U.S. Department of Agriculture, Soil Conservation Service, Series 1959, no. $19,124 \mathrm{p}$.

Lloyd, O.B., Jr. and Growitz, D.J., 1977, Ground-water resources of central and southern York County, Pennsylvania: Pennsylvania Topographic and Geologic Survey, Water Resources Report 42, 93 p.

McGreevy, L.J. and Sloto, R.A., 1976, Selected hydrologic data, Chester County, Pennsylvania: U.S. Geological Survey Open-File Report, 138 p.

1977, Ground water resources of Chester County, Pennsylvania: U.S. Geological Survey Water Resources Investigation 77-76, 76 p.

Miller, R.A., Troxel1, John, and Leopold, L.B., 1971, Hydrology of two sma11 river basins in Pennsylvania before urbanization: U.S. Geological Survey Professiona1 Paper 701-A, 57 p.

Nutter, L.J. and Otton, E.G., 1969, Ground-water occurrences in the Maryland Piedmont: Maryland Geological Survey Report of Investigations 10, $56 \mathrm{p}$.

Olmsted, F.H. and Hely, A.G., 1962, Relation between ground water and surface water in Brandywine Creek basin, Pennsylvania: U.S. Geological Survey Professional Paper 417-A, 21 p.

Rasmussen, W.C. and Andreasen, G.E., 1959, Hydrologic budget of Beaverdam Creek basin, Maryland: U.S. Geological Survey Water-Supply Paper 1472, $106 \mathrm{p}$.

Ripple, C.D., Rubin, Jacob, and van Hylckama, T.E.A., 1972, Estimating steadystate evaporation rates from bare soils under conditions of high water table: U.S. Geological Survey Water-Supply Paper 2019-A, 39 p.

Sawyer, R.M., 1963, Effect of urbanization on storm discharge and groundwater recharge in Nassau County, New York: U.S. Geological Survey Professional Paper 475-C, p. C185-C187.

Trescott, P.D., Pinder, G.F., and Larson, S.P., 1976, Finite-difference model for aquifer simulation in two dimensions with results of numerical simulations: U.S. Geologica1 Survey Techniques of Water-Resources Investigations, Book 7, Chapter C1, 116 p. 


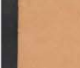

